NBER WORKING PAPER SERIES

\title{
HEALTH POLICY IN THE CLINTON ERA: ONCE BITTEN, TWICE SHY
}

\author{
David Cutler \\ Jonathan Gruber \\ Working Paper 8455 \\ http://www.nber.org/papers/w8455 \\ NATIONAL BUREAU OF ECONOMIC RESEARCH \\ 1050 Massachusetts Avenue \\ Cambridge, MA 02138 \\ September 2001
}

Prepared for the conference "Economic Policy During the 1990s," Jeffrey Frankel and Peter Orszag, organizers. We are grateful to Gary Claxton, Nancy Ann DeParle, Jeff Frankel, Victor Fuchs, Larry Levitt, Joe Newhouse, Len Nichols, Peter Orszag, Kip Viscusi, and Richard Zeckhauser, for helpful comments and to the National Institutes on Aging for research support. The views expressed herein are those of the author and not necessarily those of the National Bureau of Economic Research.

(C) 2001 by David Cutler and Jonathan Gruber. All rights reserved. Short sections of text, not to exceed two paragraphs, may be quoted without explicit permission provided that full credit, including $\odot$ notice, is given to the source. 
Health Policy in the Clinton Era: Once Bitten, Twice Shy

David Cutler and Jonathan Gruber

NBER Working Paper No. 8455

September 2001

JEL No. I1, H5

\begin{abstract}
$\underline{\text { ABSTRACT }}$
This paper reviews the formation and outcomes of health policy making during the Clinton Administration. We begin by reviewing the state of the health economy at the dawn of the Clinton era. We then review the promise and pitfalls of the Health Security Act, and its implications for all health policy that followed. We then turn to discussing accomplishments and failures in a variety of other areas of health policy: coverage expansions; insurance market regulation; Medicaid reforms; long term care; tobacco regulation; and other public health. We conclude that the dramatic failure of the HSA led to a very cautious and incremental approach to health policy making in subsequent years, but that viewed from the perspective of that that low point the health policy gains in the Clinton years were actually quite substantial.
\end{abstract}

David Cutler

Department of Economics

Harvard University

Cambridge, MA 02138

and NBER

dcutler@harvard.edu
Jonathan Gruber

MIT Department of Economics

E52-355

50 Memorial Drive

Cambridge, MA 02142-1347

and NBER

gruberj@mit.edu 
At the dawn of the Clinton era, health care was poised to be one of the major issues of the coming decades. Health care costs were rising at a rapid rate and had been doing so for well over a decade. The number of uninsured was steadily rising, and the recession of 1990-91 had brought fears of uninsurance to the ranks of the middle class. Employers were increasingly shifting the costs of insurance to their employees, and employees were afraid to switch jobs for fear of losing their health insurance. Despite leading the world by a large margin in health care spending, health outcomes in the U.S. were no better than other developed countries in dimensions such as life expectancy and infant outcomes. This combination of rising costs, high uninsurance, and poor outcomes led to a crisis mentality in the U.S. health care system Moreover, a defining political event of the early 1990s brought health care to the national stage. The election of Senator Harris Wofford of Pennsylvania on a platform of major health care reform showed that this was an issue the public cared about. Candidate Bill Clinton embraced health care reform. The public responded favorably. Public opinion polls showed that health care ranked third on the list of voter concerns in the 1992 election, behind the economy and the federal budget deficit. With Clinton's ascension to the White House, there was every expectation that major health care reform would follow.

Clinton took on the issue full force. The Health Security Act (HSA) was one of the first major initiatives of the new Administration. Demonstrating his commitment to he issue, the President appointed his wife, Hillary Clinton, to draft the plan. It was the first time that a first lady had ever had direct involvement in the policy process. The HSA was an impressive and ambitious proposal that provided a detailed blueprint for a national health plan. 
But it went spectacularly awry. The HSA failed dismally in the legislative process, resulting not only in the defeat of the plan but ultimately in loss of Democratic control of the Congress. Republicans at one time hoped to use the issue to unseat President Clinton in 1996 as well. The defeat of the HSA was felt not only in future health care debates, but in everything the Administration accomplished, or attempted to accomplish, over the remainder of its tenure. It taught the Administration a central lesson: no longer would the Administration attempt to get out in front of the legislative branch or lead the public on major health initiatives (nor, in general, in areas outside of health care either). Rather, it would pursue bite-sized, less controversial, policies with limited scope for legislative failure and reliance on executive order as much as possible. The Administration never approached another problem like the HSA. Once bitten, twice shy; the Administration learned the lesson of the HSA extremely well.

The irony is that bite size policy was quite successful. The Clinton Administration accomplished an enormous amount in health care. The record looks small only in comparison to what might have been, not in comparison to past Administrations. Out of the ashes of failure came significant success, although significant problems remain.

In this chapter, we review the health care accomplishments and failures of the Clinton era. We begin, in Part I, by discussing the health care market in the early 1990s. This is key to understanding the Health Security Act, the central health care initiative of the Administration. We review the politics and policy of the HSA in Part II. We then turn to other areas in which health policy was made, or attempted to be made, throughout the Clinton years. With universal coverage out, the Administration pursued incremental insurance expansions. We discuss these policies in Part III. In Part IV, we turn to insurance market reform, another residue from the 
HSA. Part V focuses on initiatives in the area of long term care.

Parts VI and VII then turn from health insurance and health care to public health issues.

We first discuss tobacco policy, a particularly interesting area because it represents the one other arena in which the Administration tried another ambitious initiative. It too failed - legislatively, if not substantively. In truth, the tobacco wars were ultimately favorable for the Administration's goals. We then turn to other public health initiatives, which were much more modest but also much more successful. Part VIII concludes.

At the outset, we note for the reader our own biases. We each took part in the Administration as insiders - Cutler in the HSA and Gruber in the CHIP and tobacco debates. We do not attempt to hide our personal views. A retrospective cannot be written in a vacuum, and ours has perhaps a sympathetic tilt. Readers can apply a different filter if they choose. We also leave aside issues of Medicare. Medicare proposals were constant throughout the Administration, from the HSA to calls for prescription drug coverage later on. This are reviewed in a different chapter, however.

\section{The Economic Setting}

To understand the essential parts of the Clinton health care agenda, it is important to revisit the state of health care in 1992. Health care financing had been a perennial topic on the public agenda at least since Franklin Roosevelt. The United States was (and is) the only major country without universal health insurance coverage. Universal insurance coverage became the defining health care issue. Enacting universal health insurance coverage would make whichever President did so the successor to Franklin Roosevelt's Social Security and Lyndon Johnson's 
Medicare. The moral case for universal health insurance coverage was strong as well. Harris Wofford was elected to the Senate in 1990 arguing that if prisoners had the right to basic medical care, middle class people should as well.

But there was an economic rationale as well. One argument made in the 1980s against increased government support for health insurance was that a period of economic growth would substantially alleviate social problems of this form. It would give employers incentives to provide health insurance and workers access to the type of jobs that came with health insurance.

As figure 1 shows, however, this was not the case. The share of the population that was uninsured actually increased over the 1980 s, a pattern to be repeated in the even more spectacular growth of the 1990s. True, the recession of 1990-91 particularly exacerbated this trend, with the number of people who were uninsured rising by 4 million from 1989 through 1992 (EBRI, 2000). But, looking at these trends, an increasing share of analysts came to the view that the lack of health insurance was a structural problem requiring substantial government involvement, not a temporary problem to be solved by increased economic growth.

Uninsurance was not just a problem of the very poor. Figure 2 shows insurance coverage in 1990 by family income. Among those with income below the poverty line (roughly $\$ 15,000$ for a family of four in 1990), about one-third were uninsured. A relatively similar share of the 'lower middle class' (between poverty and twice poverty) were uninsured as well. This group was to be a key constituency in the rise and fall of the Clinton health plan, as discussed below. It wasn't until higher up in the income scale (roughly about $\$ 50,000$ in annual income) that the share of people who are uninsured became very low.

Middle class anxiety about health care was relatively new. Where previously middle 
class jobs were a key to lifetime health security, that was no longer perceived to be the case. The fact that many people in this group knew people who were uninsured, particularly in the recession, contributed to this perception.

But structural changes of the 1980s also explain the increased anxiety of the middle class about health care. After the recession of the early 1980s, cost cutting became a key issue for employers. Health insurance costs were high and growing rapidly. Thus, they became a natural target. Employers cut back on health coverage or increased its costs to employees. This concerned workers greatly.

Some intrusion of economic theory is appropriate here. Economic theory does not view employers (or shareholders, their manifestation) as paying the cost of health insurance. Rather, if workers value health insurance at its cost, they will pay for it in the form of lower wages (Summers, 1989). Indeed, empirical evidence generally finds a negative correlation between benefit costs and wages in setting that are designed to test for this (Gruber, 1994; Sheiner, 1999). Thus, employers should not have cared about the increasing cost of health insurance in the 1980s. But employers clearly did not have that view, nor did workers. Employers saw themselves as paying for health insurance costs through higher prices for their products and/or lower profits. Individuals saw a clear distinction between their employer paying for health insurance and paying themselves. Politicians, hearing from workers and businessmen, mirrored this view. Thus, 'political incidence' or 'public incidence' was very different from economic incidence.

There are several possible reasons for this discrepancy, some substantive and some reflecting misperception. First, the offset reasoning is based on general equilibrium points that 
are not always obvious. No employer perceived himself as paying lower wages when health insurance costs rose. Rather, overall demand for labor falls, and the result would be downward pressure on wages in general. But any individual employer could reap the benefits if he could lower health insurance costs on his own. And conversely, if his competitor lowered costs and he did not, his competitor would drive him out of business. Thus, businessmen thinking in a partial equilibrium framework might not perceive that they did not bear the burden of health insurance costs.

Second, the ability to pass costs back to workers may also be limited for low wage workers or workers with a higher earning spouse. Where high wage workers might be willing to pay for health insurance in lower wages, low wage workers were less willing to: minimum wage constraints bind for some of these workers, low incomes in general reduce the demand for medical care, and the ability of these workers to receive free or publicly subsidized care reduced their willingness to pay for cost employer benefits. Further, workers obtaining coverage from a spouse would be unwilling to give up cash income to pay for insurance through their own employer as well. Firms with a predominance of married women, for example, might not be able to pass costs back to employees as easily as firms with married men.

Third, the economics model of incidence is distinctly a long run model. Adjustment to labor market equilibrium may occur quite slowly. This can be particularly true if incidence occurs not through cutting (sticky) nominal wages but rather by eroding the growth of real wages. At the time (as now), inflation was low, so real wage cuts were difficult. But workers and employers may be much more focused on the very short run, so that the long run adjustment of wages is less relevant to their deliberations than it is to economists' models. 
Finally, the discrepancy may reflect a difference in time perspective. In the short run, one would expect less offset than in the long-run, since wages become more flexible over time. Employers and workers may have been focusing on this short-run situation rather than the longrun analysis that most economists typically use.

For some combination of these reasons, health insurance costs became a target for employers in the newly competitive economy. Employers responded with a sustained effort to reduce their health insurance coverage, particularly for the poor (Cutler and Madrian, 1998). Jobs that could be outsourced were, to firms that generally did not pay for health insurance for their workers. Workers were made part-time or temporary in part to save on benefits costs. Employee costs for health insurance were increased to induce some people to drop coverage: the share of employers paying the full cost of insurance for family policies fell from 46 percent in 1983 to 24 percent in 1993, and for single policies it fell from 67 percent in 1983 to 39 percent in 1993 (Gruber and McKnight, 2001). And employers increasingly moved workers into managed care, which had lower premiums but less provider choice. Where managed care accounted for 8 percent of the privately insured population in 1980, it had risen to 45 percent by 1992.

Many of these measures reduced insurance coverage among the working poor. It is interesting to note that this decline was not due to reduced employer offering of insurance, but rather reduced takeup by employees, perhaps due to higher employee premium shares and outsourcing (Cooper and Schone, 1997; Farber and Levy, 2000).

Changes in the insurance industry added to this problem. Historically, health insurance was community rated: all groups paid close to the same cost, regardless of the expected cost of the group. Community rating arose because insurance was perceived to be a community activity 
(the first health insurers were not-for-profit) and because determining the expected cost for any particular group was too difficult. The spread of computer power and increased competitiveness among insurers led to a change in this policy.

Increasingly, health insurance became experience rated: groups were charged on the basis of their expected cost (Cutler, 1994). This was true even among small firms, where average costs can be quite variable (if one person develops AIDS, for example). Thus, people became concerned that their insurance coverage would be dropped if they became sick, or their premiums would increase so much that they could not afford insurance.

The economics of risk segmentation are worthy of some discussion. If insurers can differentiate sick from healthy and charge appropriate premiums, why should we care? The market is superficially efficient: everyone can get full insurance, and they do so at actuarially fair rates. Understanding the problem requires an ex ante assessment, before people know if they are sick or healthy. Risk averse people without knowledge of their future health status would choose to insure against the risk that they will become sick and then face high premiums, by guaranteeing to pay more when they are healthy. Such insurance is not carried out ex post, however, when the sick are charged more than the healthy. The loss from risk segmentation is this inability to buy insurance at average rates when sick. The risk of moving into the outer tail of the risk distribution was what people were concerned about.

An outgrowth of risk segmentation was the increasing fear that workers had about changing jobs. People were worried that if they changed jobs, they would lose their insurance coverage, either because they would move to a job without insurance, or because their preexisting conditions would not be covered under their new insurance policy. Such "job lock" was 
commonly listed as a concern in public opinion polls, and a number of economic studies over the past decade have shown that job lock may reduce mobility among those with insurance by as much as one-quarter. ${ }^{1}$ It was these fears that led to the title of the Clinton health reform plan: the Health Security Act.

The final concern was about the cost of medical care. Public and private health insurance costs had been increasing for decades at rates well above the growth of national income. As the cost of medical care increased, however, the dollar increases associated with these high growth rates became larger. Figure 3 shows average spending per person on medical care in real (1990) dollars. Where medical care costs averaged $\$ 650$ in 1960 and $\$ 1,900$ in 1980 , they averaged $\$ 3,500$ in 1992.

At least in the political arena, the increase in medical care costs over time was largely seen as a problem of price inflation, not increased service utilization. This was particularly the case with pharmaceutical costs, the most noticeable out-of-pocket cost, but was perceived to be true about other items of medical spending as well. The judgment that price inflation was the source of medical care cost increases contributed to the view that costs could be reduced without substantial adverse impact on health - just stop providers from raising prices so much. Economic research began early in the decade but particularly afterwards suggests that this conclusion is wrong (Newhouse, 1992; Cutler, 1995; Peden and Freeland, 1995). Medical care cost increase is now seen as predominantly, if not exclusively, a result of increased service utilization. The price increase view justified public involvement in controlling medical care. The new service increase makes the welfare analysis of limiting spending more difficult. With the exception of pharmaceuticals, where concern is still expressed about price inflation, this view 
has made substantial inroads in the policy arena as well.

These cost increases were a burden for the public and private sectors. In the private sector, employers were (irrationally, according to economic theory) concerned about their health insurance costs. They responded to rising costs by changing their benefits substantially. The problem was particularly acute in the public sector. Medicare and Medicaid together spent $\$ 200$ billion in 1992, about 14 percent of the Federal budget. They were also a significant factor contributing to future budget deficits. According to projections in 1992, federal health care spending would increase by between 10 percent per year between 1992 and 2000. Tax revenues, in contrast, were projected to increase by only half that amount.

For an activist President who wanted to spend money on social policies, the only way to do so was to reduce the growth of Federal medical care costs. President Clinton put it directly in introducing his health reform plan in September 1993: “[T]he budget we just adopted had steep cuts in defense, a five-year freeze on the discretionary spending, so critical to reeducating America and investing in jobs and helping us to convert from a defense to a domestic economy. But we passed a budget which has Medicaid increases of between 16 and 11 percent a year over the next five years, and Medicare increases of between 11 and 9 percent in an environment where we assume inflation will be at 4 percent or less. We cannot continue to do this. Our competitiveness, our whole economy, the integrity of the way the government works, and ultimately, our living standards depend on our ability to achieve savings without harming the quality of health care."

This was the situation facing the Clinton Administration in 1992: persistent and increasing rates of uninsurance; a middle class that was concerned about being dropped or forced 
out of insurance coverage; and rising medical care costs that made employers, and particularly the government, nervous. The proposed solution to this problem was the Health Security Act.

\section{The Health Security Act}

The Health Security Act (or HSA) was a defining issue for the Clinton Administration in many ways. It was extremely high profile. The President's wife led the reform effort, an unprecedented step historically. It was also the most spectacular failure of the Administration, and it led to the strategy that subsequently infused the Administration throughout: take small, popular steps to achieve commonly sought goals, but don't overreach.

\section{Structure of the HSA}

The HSA was designed to address each of the problems discussed in the previous section; see Cutler (1994) for a longer discussion. It is useful to review the HSA in some detail even though it did not pass; the HSA demonstrates more than anything else the health care goals of the Clinton Administration. We focus on the provisions of the HSA for the non-elderly population. Changes for the elderly were fewer and involved mostly new benefits for prescription drugs and long-term care. The provisions for the non-elderly were the heart of the proposal.

Universal coverage was the most notable feature of the plan. Everyone would be insured, in all situations. Universal coverage requires a mandate that someone pay for health insurance; it also requires subsidies, since the poor cannot afford all of the costs for insurance on their own. There are three types of payment systems that can be enacted to guarantee universal coverage. The first is an employer/individual mandate: require employers to pay for most of health 
insurance costs and individuals to pay for the rest. Non-workers are covered through their own payments, along with subsidies. The second strategy is an individual mandate alone: require individuals to pay for insurance, regardless of whether their employer contributes part of the cost. Single payer, funded by general taxation, for example through a consumption tax, is a third option.

The Health Security Act chose the first option: a combination employer/individual mandate was proposed, with subsidies for low income families to afford their payment and for small firms. The choice of an employer mandate reflected the 'political incidence' noted above; people thought it was better if their employer paid for health insurance than if they did. This was also the situation that was familiar to most Americans, who worried that without a mandate for employers to pay for health insurance, employers would drop or eliminate their current payments (without increasing their wages).

One also had to specify how people would get insurance, and the price they would pay. It does no good to require a family to pay for insurance if one member is very sick and the price is high. The risk segmentation problems noted above were particularly important here; because of changes in the insurance market, the plan had to group people together to get community rates. The solution was to set up regional 'health alliances'. All firms except the very largest ones (who, in effect operated their own alliance) had to purchase insurance from a common pool, set up on a regional basis. Insurers would be required to offer standard plans - an HMO, PPO, or indemnity plans - and enroll all who wanted. Rates would be the same for everyone in the pool. In addition to guaranteeing insurance coverage, the regional alliances were a key element of cost containment. 'Managed competition' was the buzzword; the idea is that by standardizing 
benefits and prohibiting selection, competition among insurers would focus on price and quality, not selection of risk. Anecdotal evidence from the effect of competition in lowering premiums in California (Zwanziger and Melnick,1988) and Minnesota (Feldman and Dowd,1993) supported the concepts behind the plan.

Regional health alliances became a bureaucratic nightmare that partly explained the defeat of the Clinton plan. But it is interesting to note as a historical matter the resurgence of regional alliances (under different names) in the subsequent years. Periodic Republican proposals have also supported regional purchasing pools to achieve cost savings in insurance. And a sizeable share of recent proposals for incremental health insurance reform as part of a project sponsored by the Commonwealth Fund (Glied, 2000) also centered around some type of pooling mechanism; the Federal Employees Health Benefit Plan repeatedly is used as a popular example of such a type of mechanism. One way or another, the concept of regional pools has survived the Health Security Act.

Low income families cannot pay for all of the cost of health insurance, and it was perceived that low wage firms could not either. Thus, subsidies were designed to reduce the cost of health insurance for these groups. The employer subsidies in particular were somewhat awkward. Small firms were believed to need subsidies, but only small firms with low average wages. Redistribution is difficult at the firm level, and the targeting could have led to substantial gaming by employers. Because health insurance is expensive and the subsidies would apply to everyone in an income group, not just those who were currently uninsured, the subsidy system was expensive. The subsidies were estimated to cost about $\$ 70$ billion per year when fully phased in. 
The money for these subsidies had to be found somewhere. Broad-based new taxes were not a politically realistic option. The only tax increase in the proposal was an increase in the Federal excise tax on cigarettes, from $\$ .24$ per pack to $\$ .99$ per pack. This was not a significant share of the revenue needed, however.

Most of the money for the subsidies came from slowing the growth rate of health care costs, particularly Medicare and Medicaid, but also private insurance premiums. The rationale for public savings was explicitly to free up money for expanded insurance coverage. The limit on private insurance premiums was partly for the same reason. Since the Federal government would be paying for a large part of private health insurance costs (through subsidies and the tax exclusion of employer-provided health insurance payments), the government had an interest in managing those costs. Further, the perception that cost increases reflected inflationary price increases on the part of providers and insurers justified premium controls to limit spending. And the premium limits were also implemented to provide some certainty to businesses now facing the cost of a health insurance mandate. But the cap on private insurance premiums was thought of as a backstop by many advocates of managed competition, who believed competition among plans in regional alliances would reduce costs more than sufficiently.

\section{The Demise of the Health Security Act}

When the Administration began designing its health reform plan in the spring of 1993, 71 percent of people approved of what they heard or read about the plan. By the middle of 1994, only 33 percent of people believe the Health Security Act would be good for the country. Ultimately, nothing emerged directly from the Health Security Act. 
What happened? That is a complicated question, well beyond the scope of this (economic) chapter. But some factors bear mentioning. ${ }^{2}$ The first explanation for the failure of the HSA was a poor policy design process. Appointing the President's wife to lead the health reform effort limited internal debate. This was coupled with the seeming intransigence of Ira Magaziner, the reform's chief architect, to listen to alternative points of view. As a result, debates were stifled internally and an acceptable plan was never put forth. The paper by Orszag, Orszag, and Tyson in this volume concludes that the policy process used in the health reform effort was a very poor one compared to the process used in other economic matters. In a complex matter such as health care, producing a high quality reform plan may be particularly important.

Process was also be important in the interaction with Congress. The Administration decided early on to draft the HSA without any pretense of bipartisan cooperation. Rather than working quickly to use the constellation of a Democratic Congress and White House to introduce the outlines of a health plan in the initial days of a new Administration, the process was laboriously dragged out, going past the middle of 1994 . This was partly designed to give the President's other priorities time to work their way through the legislative process (NAFTA, the economic plan), but also gave opponents time to galvanize around key issues as they (inevitably, despite attempts at secrecy) leaked out.

A second explanation stresses not process but political fighting. In 1993 and 1994, far right Republican leaders were beginning to assert their power over the Republican party, and saw defeating the Health Security Act as a key to doing so. Newt Gingrich led the opposition to the HSA and was followed by other, like-minded Republicans. This was combined with intense 
lobbying from groups opposed to aspects of the HSA. Most prominent among these were the National Federation of Independent Businesses (NFIB), the trade group for small businesses, and the Health Insurance Association of American (HIAA), the lobbying organization for health insurers.

In each case, the opposition was economic. The NFIB opposed the employer mandate, fearing that they would bear the burden of the mandate - again, not agreeing that they would be able to fully pass through the costs. The HIAA was dominated by small insurers, who made profits by finding healthy groups to insure and charging them below-market rates. The inability to do this under the HSA was a chief concern for this group. The HIAA sponsored the famous Harry and Louise ads, featuring the middle aged couple discussing the Health Security Act and concluding "There must be a better way".

In the immediate aftermath of the failed health reform effort, the Clinton Administration blamed these political considerations for the failure of the health reform plan. To our eyes, though, these explanations look less credible over time than they did at the time. Not only did the Clinton plan fail, but other reform efforts in this cycle and past political cycles failed as well. Perhaps there is a structural reason why health care reform is difficult to enact in the United States.

One such explanation is distributional: the Health Security Act, as would any universal coverage effort, involved significant redistribution, and this has historically been difficult to achieve. $^{3}$ The redistribution was at several levels: by income, by geography, by family type, and between firms providing and not providing insurance. Income redistribution was probably the most important. The primary beneficiaries of the coverage increases were lower income groups - 
not the very poor, who were already covered by Medicaid, but the lower income working population, which did not have access to either Medicaid or employer-sponsored insurance. With the exception of an increase in the cigarette excise tax, the money for the subsidies was to come from reduced growth rates of health insurance premiums.

But this source of revenues was ultimately not convincing. There were two, ironically contradictory reasons for this. First, people did not believe the savings would materialize. The lack of any explicit revenues led many people to be belief that the plan would lead to increased deficits. This was supported by Congressional Budget Office projections that the plan would cost more than the Administration estimated. In an era of mounting concern about the deficit, people feared alternately that the Health Security Act would increase the deficit, or that a future tax increase would be necessary to pay for it.

Second, people thought that if the savings were realized, they would come at too high a price. Fears that the Health Security Act would lead to rationing of health care were widespread. And asking the middle class to pay for health care for the poor by rationing their own use of services was not popular. Support for the Clinton plan fell most prominently among those who would be asked to sacrifice.

Indeed, the entire focus on universal insurance coverage and transfers to the poor drove attention away from what the middle class was supposed to get out of the plan. Research by political scientists has suggested (Blendon, Brodie, and Benson, 1995) that middle class people turned off from the Clinton Plan because they wanted the focus to be on their personal health care problems, not the problems of the health care system. The middle class perceived itself as having three goals: (1) making sure they don't lose insurance coverage when they change or lose 
their job; (2) making sure they are not charged more if someone in their family gets sick; and (3) reducing the insurance premiums and out-of-pocket costs they and their employers had to pay. Universal coverage is not on this list; regional health alliances are only dimly related to these goals and sound like big government. Government-enforced caps on insurance premiums might lead to rationing.

The decline in support by the middle class was the most notable change in public opinion over the course of the Clinton Plan. Where three-fifths of those earning $\$ 20,000$ to $\$ 30,000$ supported the Clinton Plan in September 1993, only two in five did so in April 1994.

In summary, the middle class wanted to have more but pay less. But this is of course impossible, and until this is widely accepted, there is bound to be disappointment among those endeavoring to achieve national health insurance. The failure of health reform may be because no Administration can meet the unreasonable expectations of the vast majority of people.

A fourth explanation for the decline of the Health Security Act is that the problems driving the health care concern abated. Health concerns were most prominent in the recession of 1990-91, when people feared losing their job and thus health insurance. As the economy expanded in 1993 and 1994, fear of job loss receded. It is an ironic feature that the Administration's successful effort to promote macroeconomic growth helped to kill one of its signature social insurance programs.

Whatever the reason, the Health Security Act failed badly in the political arena. After a lengthy Congressional debate, the HSA was pulled in 1994. It was a bitter time for the Administration. 


\section{Lessons from the HSA}

The Administration drew several lessons from the failure of the Health Security Act, which drove health policy for the remaining years. We summarize these lessons and in the remainder of the chapter discuss how and when they were applied.

\section{Lesson 1: Broad based coverage expansions are out.}

The Administration never again proposed a large scale expansion of insurance coverage. Rather, coverage expansions were targeted to specific groups in the population where a strong case could be made that insurance coverage was a clear need. We term this the 'Titanic strategy', because in practice it meant saving the women and children first.

Thus, the Administration's most notable coverage expansion - a quite large policy, albeit small relative to the Health Security Act - was the Children's Health Insurance Program (CHIP), which provided public health insurance coverage to low income children. It was always easy to sell coverage expansions for children. Even in the 1980s, the Democrats forced the Reagan Administration to expand Medicaid coverage for children. The Administration's focus on children was a clear case where the public could be convinced to spend additional money.

The other initiatives were even more targeted: a buy-in to Medicare for the near elderly; coverage for the unemployed; coverage for the parents of CHIP children (it's unfair for the children to have coverage but not the parents); and substantial new benefits for the elderly.

It is ironic that the Administration was never again able to approach the issue of broad based coverage expansions, since the 'structural' view of the problem seems even more correct in retrospect. Figure 1 shows the rate of uninsurance over the 1990s. Even in the boom economic 
times of the 1990s, rates of uninsurance rose. There is no longer any credible case that if the economy just grew faster, the health insurance problem would get better. Indeed, it is quite possible that the next recession will reawaken the fears about health insurance coverage that propelled the Health Security Act.

\section{Lesson 2: Focus on Middle Class Concerns}

The fear of being dropped from coverage, losing coverage when changing jobs, or having insurance premiums increase when someone becomes sick did not go away with the demise of the Health Security Act. At first, states took up the issue. State governments passed legislation limiting the extent to which insurers could discriminate against the sick. The Federal government followed the states in 1996, with the Health Insurance Portability and Accountability Act (HIPAA, also called the Kassebaum/Kennedy legislation). This legislation reduced some of the most complained-about features of private insurance and attempted to reduce costs by standardizing medical record keeping, but it was not entirely successful, as we review below.

\section{Lesson 3: Don't Get Too Far Out In Front}

The final lesson is that it is dangerous to get too far out in front of the public. After the Health Security Act, the Clinton Administration generally waited for issues to bubble up from the public, judging the public mood and proposing policies appropriate to it. Thus, the Administration was a latecomer to tobacco litigation, pushed HMO regulation only when the problem garnered substantial public attention (and even then not with the full vigor of many Democrats) and seized on smaller issues such as privacy protection, medical errors, record 
keeping, etc. As with the CHIP program, many of these were successful interventions, but they frequently rode the wave of public opinion, rather than leading the public to a new position.

\section{The Health Care Market, Post-HSA}

The failure of the HSA was a defining event in private markets as well. Since the mid1980s it had been widely expected that some health care legislation would be enacted, probably with universal insurance coverage. Thus, employers were shy about making long-term changes in their benefits plans that would be changed again soon. With the failure of the HSA, employers realized this would not happen. Given their view of incidence, employers became increasingly concerned about how they would afford health care benefits.

The result was a head-long rush into managed care. Those employers that offered managed care plans before the HSA tilted their pricing to encourage employees to enroll in them. Those that offered only conventional plans often gave those up for managed care options. By 1996, less than 5 percent of the privately insured population was enrolled in traditional fee-forservice insurance. The rest were in some form of managed care - managed indemnity insurance sometimes, PPOs, HMOs, and other combinations as well.

The result of all of this, when combined with very rapid economic growth, was a substantial reduction in the share of GDP that was going to health care, at least relative to baseline projections. Where forecasts in 1992 predicted that health care would rise from 14 percent of GDP to nearly 20 percent by 2000, actual health spending in 2000 was still but 14 percent of GDP. The implied reduction in spending was about $\$ 100$ billion.

The reductions carried over to public programs as well. With managed care cutting fees 
for physicians in the private sector, Medicare and Medicaid did the same. Where managed care lowered utilization volume for privately-insured people, providers carried these over to the elderly as well. As a result, Medicare and Medicaid experienced very low rates of cost growth over the 1990s, particularly from 1997 onwards. Indeed, this contributed significantly to the improved budgetary position of the Federal government. This is exactly what the Administration had hoped the HSA would do, but it happened even in the HSA's defeat.

But all was not rosy. The share of people without insurance continued to climb in the 1990s, even with moderate health care cost increases and a stunning period of economic growth. Policies such as the CHIP expansion (discussed below) mattered, but not enough to offset the tide of other factors. And providers and patients alike are growing increasingly dissatisfied with managed care as a "solution" to our health care problems. So, we enter the $21^{\text {st }}$ century with an even more structural problem than when President Clinton took office - there is no conceivable hope that insurance coverage will increase without substantial public policy action. With HSAlike options off the table, however, it is not clear where the answers lie.

\section{Incremental Approaches to Expanding Health Insurance Coverage}

In the wake of the HSA's failure, the Clinton administration, as well as many legislators who wanted to expand insurance coverage, clearly recognized that incremental approaches to coverage expansions were the only feasible route. For some, incremental approaches to coverage were desirable on policy grounds, as the most cost-effective means of addressing particularly important parts of the uninsured population. For others, incremental approaches were a means to an end, national health insurance coverage. But both groups recognized that, whatever their goal, 
politics dictated that this was the route to take.

In this section, we review the incremental approaches to expanding health insurance coverage pursued during the Clinton years. We first set the stage by discussing the economics of incremental insurance expansions, and by briefly reviewing the evidence on the incremental insurance expansions that preceded the Clinton years. We then turn to a discussion of the major initiatives of the Clinton era, within the context of this theory and evidence. We conclude with an overview of what was and wasn't accomplished.

\section{The Theory and History of Incremental Insurance Expansions}

There are many potential goals for incremental expansions, and they are often in conflict. The most straightforward goal would be to maximize the number of newly insured for a given budgetary cost, or to maximize the bang-for-the-buck of insurance policy. This is often called target efficiency.

Target efficiency, in turn, is related to "crowdout." The uninsured population is not that distinct from the insured population. As the saying goes, dolphins and tuna swim closely together. Almost 60 percent of the uninsured have family incomes over $\$ 20,000$ per year; indeed, 21 percent of the uninsured have family incomes over $\$ 50,000$ per year. Yet, among those with family incomes of more than $\$ 20,000$ per year, only 14 percent of persons are uninsured, and 82 percent are privately insured. So any policy that is targeted purely to income, as most incremental approaches are, will by its nature be operating in a range where there are many insured persons for every uninsured person that the program is trying to attract.

The potential problem this causes is that those enrolling in the program will not just be 
the uninsured, but also those insured who find public insurance attractive. As Cutler and Gruber (1996) note, the typical insured person pays about one-third of the total costs of their medical care, while public insurance has traditionally been completely free. Thus, if many of those with private insurance are made eligible for public insurance, they may be "crowded out" of their private plans onto the public rolls. This will reduce the bang for the buck of public insurance expansions, as dollars of spending rise but net insurance coverage does not.

It is fundamentally impossible to target a policy purely to those who are currently uninsured, since there is no way to tell exactly who would or would not be insured in the absence of the new program. Rather, minimizing crowdout means finding mechanisms which best cull out those who would otherwise be uninsured from the total population. One way to do this is to change the benefits that are offered. Less generous benefits, either less attractive coverage or charging people more, attract fewer of those with private insurance than do more generous benefits. But they also confer less benefits on recipients. Other barriers to enrollment, "ordeal mechanisms" such as waiting lists, that make public insurance less attractive to those who would otherwise be insured while still making it useful for those who are uninsured may help (Nichols and Zeckhauser, 1982).

The tradeoff is, of course, the desire to help the needy. Many analysts express concern that these mechanisms will have significant adverse effects on accomplishing the goals of the program. Moreover, if low income persons move from a poor private insurance policy to a good public insurance policy, health may improve, even though people are officially crowded out. It may be better to live with target inefficiency than to try to remove it through costly ordeal mechanisms. And even when there is crowdout, it is not without benefits: effectively, crowdout 
transfers income to those who would have otherwise had to finance their own private insurance coverage.

How one chooses the target group reflects these and other factors. Some groups have low crowdout but not much benefit from insurance. Other groups may have high benefits but severe crowdout. For policy and political reasons, there has always been special concern about ensuring high levels of insurance coverage among children. But doing so means raising income limits for public insurance eligibility into ranges where there is likely to be significant crowdout. For example, among those children in households with incomes between 200 percent and 250 percent of the federal poverty line, only 14 percent are uninsured, and almost 80 percent already have private health insurance.

Prior to the Clinton era, concerns about efficiency were not paramount. ${ }^{4}$ Until 1997 , the predominant tool of public insurance policy was the Medicaid program, which provided coverage for low income families; Medicaid also provides coverage for the disabled and elderly that will be discussed later in the chapter. Before the mid-1980s, Medicaid eligibility was tied to cash welfare policy, which meant that eligibility was largely restricted to very low income families headed by a single mother. Starting in the mid-1980s and continuing into the Clinton era, the federal government and individual states expanded insurance coverage for two distinct populations: children and pregnant women (for the expenses of pregnancy only). Children were a natural group for obvious political reasons: they could not provide for themselves. Pregnant women were also particularly important because some evidence suggested that the savings in costs for low birth weight infants from covering pregnant women could more than offset the direct costs of the insurance expansion (Institute of Medicine, 1985). 
By 1992, states were required to cover all pregnant women and children under the age of 6 up to 133 percent of poverty (independent of family composition), and were allowed to expand coverage up to 185 percent of poverty. In addition, children born after September 30, 1983, were mandatorily covered at incomes up to 100 percent of the poverty line (once again independent of family composition). And a number of states had gone beyond these limits, using their own state funds.

These Medicaid expansions tremendously increased the eligibility of low income women and children for public health insurance coverage. By 1992, almost one-half of all women were eligible for Medicaid in the event they became pregnant, and almost one-third of children age 014 were eligible for all of their medical spending (Gruber, 1997).

However, many of those made eligible for public insurance already had their own private coverage; roughly two-thirds of eligibles were privately insured before becoming eligible (Gruber, 1997). The fact that such a large share of the newly eligible population under the Medicaid expansions had access to private insurance raises the prospect that many of the new enrollees on the program may have been "crowded out" of private insurance purchases. There is a large literature devoted to the study of crowdout, and it generally concludes that crowdout is significant, although there are debates over the magnitude of this phenomenon; see Gruber (1997, 2001) and Cutler (2001) for reviews.

At the same time, several studies argue that the expansions of the Medicaid program were beneficial to public health. Currie and Gruber $(1996 a, b)$ find that Medicaid eligibility expansions were associated with increased use of preventive care and reduced infant and child mortality. But these improvements were costly; Currie and Gruber estimate a cost per infant life saved of 
roughly $\$ 4$ million dollars from the Medicaid expansions of the late 1980 s and early 1990 s. $^{5}$ This high cost may reflect the relative lack of targeting of these expansions.

First the Defense: the 1995 Government Shutdown

After the defeat of HSA, the next battle over insurance coverage in the 1990s was really a battle over the basic structure of Medicaid. Riding the wave of their "revolutionary" 1994 retaking of Congress, the Republicans in 1995 proposed in their budget to block grant the Medicaid program, giving states almost total control of what has been traditionally a very centralized federal program.

The Clinton administration strongly opposed this block grant plan, as well as the associated dramatic cuts in the Medicare program. There was enormous concern that a block grant would lead to significant reductions in insurance coverage, particularly in a downturn. The opposition to the health care provisions of the 1995 Republican budget plan (including very significant cuts in the Medicare program that are discussed elsewhere in this volume) was the nexus of the battle that led to government shutdown in the winter of 1995 . Ultimately, the Administration won. The Republicans compromised and the basic structure of Medicaid was preserved.

The Administration's principled, and ultimately successful, stand against block granting the Medicaid program stands in interesting contrast to its support of a welfare reform bill less than one year later that block granted cash welfare programs. These contradictory positions likely reflect several factors. The debate in 1995 was over a set of Medicare and Medicaid policies which were very unsavory as a package, whereas the welfare reform debate was focused 
on a single program. In addition, the variation in the Medicaid entitlement across states was much smaller than the existing variation in cash welfare benefits; in a sense, cash welfare had already been much more decentralized so there was less to "lose" (from the perspective of Democrats who prefer federal standards) from turning the program over more fully to the states. And the President had campaigned on welfare reform, so, in the face of a reelection battle, it was very hard to veto a bill that did fundamentally reform the program.

\section{Further Expansions for Children: The CHIP Program}

As the Clinton Administration entered its second term, and the wounds from HSA and the 1995 budget battle had started to heal, the focus returned to health insurance coverage expansion. The fact that a steadily growing economy had not reduced the number of uninsured was a clear precipitating factor. Of particular concern was rising uninsurance of children, which was occurring not only in the face of a growing economy, but also despite dramatic growth in the Medicaid program. Thus, children became the natural target.

The Administration, in its 1997 budget, proposed \$8 billion for children’s health insurance. In May, 1997, the Administration and the Republican Congressional leadership reached agreement on the broad parameters of a deal to balance the budget within five years, and in the context of this agreement the Senate Finance Committee raised the amount earmarked for children's health insurance to $\$ 16$ billion over 5 years. But the agreement contained essentially no detail on the nature of this new spending. Republicans, led by Phil Gramm, wanted block grants to the states to use as they saw fit for childrens' health care. They saw the existing public programs as failing, and wanted to focus more directly on delivering medical services. 
Democrats viewed the failures of the existing system as ones of scope, and wanted an expansion of existing public programs. In addition to this fight, concerns over crowdout had now entered the policy vocabulary. Finally, there were complaints from states about the rigidity of the Medicaid program and its expensive mandates.

A compromise was hammered out that resulted in the adoption of the Children's Health Insurance Program (CHIP). The compromise was much closer to the Democrats' original position, in part because Republicans gained so much else through what became the Balanced Budget Act (BBA) of 1997 (including significant reductions in capital gains taxation and the introduction of Roth IRAs). But Republicans were successful in denying a simple expansion of Medicaid. Rather, states were given the choice of either expanding their Medicaid programs, or introducing an entirely new insurance program for CHIP. This new program could offer an insurance package that was less generous than the Medicaid package, although it had to be at least as generous as one of (a) Medicaid, (b) the typical HMO offered in the state, or (c) plans offered to state employees. Moreover, states were allowed to introduce premiums and costsharing for children enrolled in families with incomes above 150 percent of the poverty line, a significant departure from the free entitlement to Medicaid that had traditionally existed.

As with traditional Medicaid, this program was not a mandate, but states were motivated to introduce CHIP programs by the promise of vast Federal subsidies. In particular, the Federal government offered to pay an even larger share of CHIP costs than of Medicaid costs -30 percent of the base match rate - so that on average the federal government would pick up about three-quarters of the program costs. But, unlike Medicaid, CHIP is not an individual entitlement, raising concerns that it will not be sufficient in difficult economic times. Finally, at the end of 
the debate, a 15 cent increase in the tobacco excise tax was added to the BBA, funding an additional $\$ 8$ billion for the program over five years.

The enactment of CHIP was clearly the high water mark of the Clinton years in terms of insurance coverage expansion. The resultant $\$ 24$ billion program (over five years) was hailed by the Administration as the largest expansion in public insurance since the introduction of the Medicaid, and the administration asserted that the program would insure 5 million of the 10 million uninsured children at its time of passage.

Both claims are, in fact, somewhat questionable. Some of the Medicaid mandated expansions of the 1980s and 1990s, particularly OBRA 1989 which mandated coverage of pregnant women and all children under age 6 to 133 percent of the poverty line, resulted in an increase in spending on new health insurance coverage that may have been equally large. And the OBRA expansions probably resulted in more new insurance coverage. Whether the CHIP program will ultimately enroll 5 million children is unknown. To date, CHIP programs have only enrolled roughly 3.3 million children (Domestic Policy Council, 2001). Part of this low enrollment, relative to the initial goals, was slow state action in taking up their CHIP entitlements. Despite the increased flexibility CHIP afforded, states did have to submit a very detailed plan on how they would spend their CHIP entitlement before they could receive their share of funds. This took time. Recently, enrollment has been increasing rapidly, and rose by 70 percent in 2000 (Domestic Policy Council, 2001).

The key question is whether the CHIP program creates more in benefits than it costs, including crowdout. By allowing states some flexibility, CHIP did establish the kind of "ordeal" mechanisms which should minimize crowdout. In addition, states were explicitly mandated to 
have a strategy for minimizing crowdout, and a number of states have considered or enacted approaches such as waiting periods. At the same time, CHIP was expanding insurance coverage into the income range where there were many more insured per uninsured child. Because real expansions are so recent, there is little evidence to date on the net insurance increase from CHIP. One promising sign is that the number of uninsured children declined in 1999 for the first time in a decade.

\section{Medicaid and CHIP refinement}

Throughout the HSA debate and continuing afterwards, a major tool of incremental coverage expansion has been innovation within the Medicaid program. States are allowed to apply for "waivers" that permit them to deviate from standard program guidelines. The Administration approved a wide variety of Medicaid waivers throughout its tenure. And, almost immediately after the passage of CHIP, states began applying for waivers from the structure of this program as well.

Most of the waivers from Medicaid applied for, and approved by the administration, were relatively minor deviations from the standard benefit package. But some were more major initiatives, in essence transforming Medicaid funds for women and children into coverage for entire families. The motivation for these waivers was partly the split in family coverage induced by Medicaid that lowered overall rates of coverage. Families may not enroll children in Medicaid if only some children in the family are eligible for care, or if only the children are eligible and the parents are not. Thus, making entire families eligible may be a way of increasing takeup among children. Indeed, recent estimates suggest that almost 7 million low income 
uninsured children in the U.S. are actually eligible for some form of public insurance (Broaddus and $\mathrm{Ku}, 2000)$. Evidence from states with plans to cover all family members suggests that this policy raised coverage of children as well.

Other reforms were proposed by the Administration. Over time, there arose an increasing sense that there were much higher returns to covering low income adults than continuing to cover somewhat higher income children. Over two-fifths of all adults below the poverty line are uninsured, compared to "only" one-quarter of children (Employee Benefit Research Institute, 2000). Thus, the Clinton administration's last major proposal on the uninsured (largely a symbolic gesture included in the 2001 budget in support of similar proposals made by candidate Al Gore) was to extend Medicaid and CHIP coverage to parents of the children on these programs. This proposal did not make much headway in legislative discussions.

Finally, the Administration turned its efforts to increasing enrollment among groups eligible for Medicaid but not taking it up, particularly children. To a significant extent, public policy has already created the mechanism for near-universal coverage of children, so that now 95\% of low income children are eligible for public insurance (Broaddus and $\mathrm{Ku}, 2000)$. The major problems at this point are extending eligibility to other groups, as in the proposal above, and enrolling those children who are eligible but uninsured.

One group of particular emphasis is children losing insurance when they leave welfare, an important but unintended byproduct of the 1996 welfare reform act. The decline in the uninsured from 1998 to 1999, the first decline in more than a decade, partly reflects the success of efforts to enroll these eligible but not insured populations, along with the CHIP expansions. 


\section{Other Initiatives}

While the incremental approach to insurance expansion was more successful than the HSA, not all incremental expansions were politically successful. Foremost among these was a proposal to provide public insurance to those between jobs, through state unemployment insurance (UI) programs. This proposal, included in various forms in the Administration's 1994 through 1997 budgets, would have provided free or subsidized coverage to those unemployed collecting UI.

Given concerns over job lock and insurance portability, this group would seem to be an attractive one for coverage expansions. But it never really gained political traction. One significant drag may have been the insistence of tying the program to UI programs, which raised both administrative and expenditure concerns among the states, as well as concerns among conservatives about the dangers of expanding UI.

Another unsuccessful proposal was to expand coverage to those early retirees who are not eligible for Medicare. As Gruber and Madrian (1996) document, early retirees face significant medical risk. Compared to those age 35-44, for example, those age 55-64 are twice as likely to report themselves in fair health and four times as likely to report themselves in poor health. They are four times as likely to have had a stroke or have cancer, seven times as likely to have had a heart attack, and five times as likely to have heart disease. They are twice as likely to be admitted to a hospital (spending twice as many nights in the hospital if admitted), and 40 percent more likely to have a prescribed medicine (having twice as many medicines if they have a prescription). As a result, the medical spending of 55-64 year olds is twice as high, and twice as variable, as that of 35-44 year olds. Yet this is a group with no access to public insurance 
options, other than if disabled.

The Administration proposed in its 1999 budget a package of options designed to increase insurance coverage for the near-Medicare population. Foremost among these was the ability for 62-64 year olds to buy into Medicare at its average price (about $\$ 300$ per month), with an additional premium paid once they turn 65 to cover adverse selection costs. ${ }^{6}$ There was also a similar buy-in option for 55-62 year old workers who involuntarily lost their jobs (and health insurance), as well as extensions of COBRA coverage to those early retirees whose retiree health insurance coverage was terminated (a group internally labeled as the "promisebreaker" population).

Once again, however, this proposal did not get very far in Congressional deliberation. In terms of the buy-in, there was enormous concern among fiscal conservatives about expanding the Medicare entitlement at a time when Medicare did not seem on stable financial footing. And there remains significant resistance to any expansion of the COBRA entitlement among the business community, which also resulted in the quick rejection of the Administration's 2000 budget proposal of a 25 percent tax credit for COBRA costs.

It is unclear why these proposals did not go further in the political process. They were tightly targeted to a relatively narrow interest group, meeting the seeming preconditions for political success in the Clinton era. But the affected interest groups, for example unions, never really rallied to the cause. Perhaps this reflected their concern that partial reform would undercut the demand for more aggressive interventions later on. The result was the quick death of all of these proposed initiatives. 


\section{Tax Policy}

A final incremental approach deserves mention, as much for the future as for the past tax-based incentives for insurance coverage. A constant debate throughout the academic community has been over the possibility of using the tax code as a means of stimulating insurance coverage. The tax code is already a major determinant of health insurance decisions, through the existing tax subsidy to employer provided insurance, whereby employer payments through wages are taxed and employer payments through health insurance are not. This subsidy was partially extended to the self-employed in 1986, as they were allowed to deduct 25 percent of the cost of their insurance from their taxes, and fully extended to the self-employed in BBA97.

Towards the end of the Clinton years, and throughout the 2000 campaign for President, focus shifted more heavily onto tax policy as a vehicle for addressing the problem of the uninsured. For example, George W. Bush's campaign platform included a credit for the purchase of nongroup insurance of $\$ 1,000$ for individuals and $\$ 2,000$ for families; this mirrored a multitude of congressional proposals for similar tax credits. Former Senator Bill Bradley had also proposed a tax credit approach in the Democratic primary.

As discussed in Gruber and Levitt (2000), however, there are important limitations to tax policy which makes it much less efficient than public insurance program expansions: the fact that about half of uninsured families don't pay taxes; that even a refundable credit would face the daunting administrative problem of advancing the credit in time to finance insurance purchases; and that and any politically realistic credit amount still leaves the uninsured with very large insurance costs (for example, the Bush credit would pay only about one-third of the cost of a nongroup family policy). As a result, take-up would not be substantial. Gruber and Levitt 
estimate that roughly three-quarters of the spending on such a tax credit actually accrues to those already covered by insurance. This is even lower target efficiency than is seen with public programs. Thus, despite their limitations, public insurance expansions remain the natural means of pursuing further reductions in the uninsured.

\section{Insurance Market Reforms: Feeding the Middle Class}

The failure of the Health Security Act did not diminish the view that some reform to insurance markets was needed. After all, the middle class was upset about their fragile ability to obtain health insurance. And there were growing concerns, particularly towards the end of the Administration's tenure, about the quality of the health care being delivered by managed care plans. These concerns led to a series of reforms and proposed reforms that were politically exciting, but ultimately economically insignificant. Insurance market reforms were more hype than true change.

\section{The Health Insurance Portability and Accountability Act}

After suitable time for reflection after the defeat of the HSA, the idea of more limited health care legislation gained currency. In particular, middle class concerns about 'job lock' losing or being denied insurance simply because a person was sick or changed jobs - had never really been addressed. Federal legislation along these lines was enacted in the Health Insurance Portability and Accountability Act (HIPAA) of 1996, also commonly known as the KassebaumKennedy legislation, after its two chief sponsors.

To understand what the HIPAA did, some knowledge of the health insurance system and 
arcane aspects of health insurance regulation is needed. People get private health insurance in one of three ways. Some people have insurance through a large firm, a firm with sufficiently many employees that the variance of average health costs is fairly small. Firms with more than 5,000 employees are generally considered large for insurance purchases, but some consider firms with as few as 50 employees large. Large firms frequently self-insure their medical risks. An insurer runs the insurance policy, but the firm takes all risk for the cost of its employees.

Other people obtain insurance as part of a small firm (a market often termed the small group insurance market). These firms have average costs that are quite variable. Thus, when insurers moved to experience rating at small group sizes in the $1980 \mathrm{~s}$, these firms faced increasingly variable premiums. Premiums were low for healthy firms or firms with good claims experience in the immediate past, but rates could jump dramatically when one employee got sick. Finally, a residual share of people purchase insurance as individuals or families in the non-group market.

The different markets are also characterized by differing degrees of adverse selection. Essentially all large firms provide insurance, while a minority of small firms do, and an even smaller share of individuals. Thus, insurers pay particular attention to small firms wanting to purchase insurance, to guarantee that these firms are not the sickest ones. This is especially true of the individual insurance market. Insurers have long feared that individuals purchasing insurance in the non-group market were the sickest of those without group coverage. Thus, insurers either avoided that market entirely or employed substantial underwriting criteria before selling insurance to those people.

Most of the regulation of health insurance up until, and in the early years of, the Clinton 
Administration took place at the state level. While it has been clear since the Supreme Court's 1944 decision in U.S. v Southeast Underwriters that the Federal government had the right to regulate insurance as interstate commerce, the McCarran-Ferguson act passed the next year legislated that the federal government would devolve regulatory responsibility to the states, so long as that state regulation was consistent with "federal purpose", which at that point was primarily focused on price fixing (Blumberg and Nichols, 1998).

The largest Federal involvement in insurance regulation was to prohibit state involvement in regulating large, self-funded insurance plans. Most self-funded plans were operated by large, multi-state employers, the large firms discussed above. These firms were worried about dealing with 50 state governments, each with different insurance rules. Thus, the Employee Retirement and Income Security Act (ERISA) of 1974 removed state insurance authority for self-funded plans. $^{7}$ States that wanted to restrict pre-existing condition restrictions for all employees, therefore, were unable to do so.

To address the issue of job lock and ability to buy insurance, HIPAA had to deal with these three markets: the large firm market, the small firm market, and the individual market. HIPAA addressed each of these situations, with varying degrees of bite.

While the HIPAA legislation was complex, its essential elements were two-fold. Most importantly, HIPAA mandated changes in group insurance markets to guarantee access to insurance in situations where people might otherwise have lost it. HIPAA imposed maximum pre-existing condition exclusions on group insurance. No firm - including ERISA-exempt firms - can exclude from coverage for more than one year any condition known about in the six months prior to starting on the insurance policy. Further, these pre-existing condition exclusions 
were waived for people moving from one job with insurance to another job with insurance, provided the person had eighteen months of coverage prior to the job change. Both of these provisions were designed to deal with the insurance portability problem.

An important point about these changes, though, is that they did not specify the price at which insurance must be offered. Thus, insurers could charge substantial amounts for people with pre-existing conditions, and that would be allowed under HIPAA. The omission of premium restrictions was by design; there was no bipartisan support for premium restrictions at the Federal level, although states were allowed to do so on their own.

HIPAA had further provisions for insurance sold to small firms - defined as firms with 2 to 50 employees. HIPAA required insurers in the small group market to sell insurance to all small groups wishing to buy it; groups could not be excluded simply because a member of the group was sick. The rules under which firms could obtain this insurance - in particular the plans they had access to and the price they had to pay - were complex, depending on other regulations the state enacted (as we discuss further below).

Finally, HIPAA made smaller changes in the non-group market. Requiring firms to offer insurance to anyone in this market was not an option; insurers were too worried about adverse selection to go along with that. Rather, the Act made it easier for certain people to get insurance without being denied care. Insurers could not exclude from coverage or impose pre-existing condition restrictions on people with at least eighteen months of continuous private coverage, who most recently had group coverage, who had exhausted their benefits under Federal continuation of coverage (COBRA) legislation, and who were not eligible for public coverage or employer-sponsored insurance through a spouse. This is a small set of people, to be sure. Again, 
the price at which these people could get such insurance was not specified in Federal legislation; it was left to the states to regulate this (and most do not).

HIPAA left so much to the states because the states were substantially ahead of the Federal government in this area. Indeed, the right way to view HIPAA is as the Federal government codifying what the majority of states had already done, not imposing a wealth of new requirements on them.

Over the course of the 1980s, states had become increasingly worried about small group health insurance issues. Unlike the Federal government, which concentrated on covering more of the uninsured, states focused much more on the problems of those with insurance. Many small businesses wanted restrictions on insurance practices. And insurers were often out of state companies, so their lobbying counted less in state capitals. Thus, state government acted long before the Federal government.

As early as 1989, states began passing legislation designed to help small firms obtain insurance. By the time of the HIPAA, nearly all states had some small group market reforms in place. The state legislation was generally similar to the HIPAA as it applied to small firms: it required insurers to offer at least some insurance products (HIPAA mandated all insurance products) to all groups of people, and it prohibited pre-existing condition restrictions in some cases. Most importantly, many states limited the variability of premiums that insurers could charge to less healthy groups. Typically, states set rating bands which insurers could not exceed. For example, some states required insurers to price all policies within 15 percent (plus or minus) of the average premium. Others required insurers to contribute to a high-risk pool for very expensive non-group cases, which would be run by the state. The HIPAA legislation allowed 
states to continue these rating reforms if they wished, effectively putting some teeth in the HIPAA regulations.

What HIPAA effectively accomplished, then, was relatively minor. It codified these state regulations, making them more uniform and expanding them in minor ways. ${ }^{8}$ It extended prohibitions on pre-existing condition exclusions to ERISA-exempt firms. It brought reform to the few states that had not passed legislation already. And it made minor changes increasing access to non-group insurance for some people.

Not surprisingly, essentially all analyses of the effect of HIPAA on health insurance markets suggest that the HIPAA legislation by itself had virtually no effect on rates of insurance coverage, premiums paid, or job mobility (Pollitz et al., 2000; Nichols and Blumberg, 1998).

And yet, like the HSA before it, passing the HIPAA legislation was quite a struggle. Congress had protracted negotiations over the issue, far disproportionate to what the legislation actually accomplished. Indeed, to get passage of the legislation, the White House and Congressional democrats had to agree to a demonstration program for Medical Savings Accounts. ${ }^{9}$ Given its incremental progress, why all the fighting? Why even pass HIPAA in the first place?

The desire for reform was largely political. In 1996, Congressional Republicans had lost the budget fights of the previous year and were on the verge of losing the Presidential election and possibly control of Congress. They wanted some positive health care accomplishment to run on (and their leadership was very focused on making at least a symbolic gesture in favor of MSAs, for ideological and constituent service reasons). Democrats wanted to establish the principle that the Federal government could act on health care, and wanted a bipartisan statement 
that some insurance market regulation was needed. They knew this legislation was not major, but hoped that it set the stage for later action. That is also why insurers opposed it. They did not fear the provisions of the HIPAA per se, but worried that it would lead to other Federal legislation that would be more onerous.

Even if HIPAA itself had no major effect, one might wonder whether the state legislation it built upon was successful. Those laws were more consequential, as they preceded Federal action. In answering this question, one needs first to decide what the goals of the legislation were. Premiums were supposed to be compressed by the legislation. There is little data on health insurance premiums paid by employers, however, so testing this is not easy. The legislation was also supposed to reduce job lock and increase labor market mobility. In principle, this can be tested. The few studies that have been done suggest no large changes in mobility as a result of the HIPAA. Finally, one hope was that more people would become insured, since the ability of insurers to deny coverage would be reduced. The literature to date suggests this did not happen.

Indeed, some studies find that insurance coverage declined slightly as a consequence of the legislation, although the estimates of insurance decline are small and a number of studies find no significant effect. A decline in coverage could be explained by the fact that insurance reform lowers premiums for high-risk firms but raises premiums for low-risk firms. As a result, some low risk firms choose to drop coverage, or their employees choose not to take it up. Of course, this may not be bad; public policy may well want to insure high risk people at the expense of low risk people. But it does not promote overall insurance coverage.

But, the small overall effects suggest a more basic problem with the insurance reform 
legislation. Fundamentally, the legislation did not materially impact the insurance market. To a great extent, this failure is a result of the complexity of insurance markets. Insurers offer more than one insurance policy and do so in many different settings. Some of the legislation required only that insurers offer a 'basic' and 'comprehensive' package to everyone. Insurers complied with these restrictions but priced the required policies very high. Purchasing firms that were good risks were offered access to different policies that had lower prices.

Other times, state mandates regarding purchased insurance were met by increases in the share of firms becoming self-insured. Insurers and firms worked out such arrangements to avoid the new legislation. HIPAA might have extended the full range of state insurance regulations to these ERISA-exempt firms, but it chose not to do so. As a result, self-insurance remains a mechanism to avoid most of the reforms that states required.

In retrospect, these actions should not be a surprise. People who are healthy do not want to pool with those who are sick. Insurers would like to cater to these desires. Thus, legislation regulating health insurance needs to constrain what both firms and insurers naturally want to do. Without very onerous regulations, this is impossible. The lesson from the HIPAA, and the state regulations that preceded it, is that partial legislation cannot constrain markets from acting in profit-maximizing ways. HIPAA was perhaps a political success, but was close to an economic non-event.

\section{Benefits Mandates}

A similar conclusion can be drawn from studying the other major insurance market reforms of the Clinton era. These other reforms were focused on addressing perceived 
limitations in the benefits being offered by private insurance plans in the managed care era. Principal among these was mental health parity. The Administration, led in this instance by the Vice-President's wife, Tipper Gore, was disenchanted with the discrimination in the common limitations on mental health coverage in private insurance plans relative to the coverage afforded somatic illnesses. Insurers were long reluctant to cover mental health on parity with other illnesses, because of a higher elasticity of demand for mental health services. This was often termed the Woody Allen effect, after the famous actor's many years in therapy. In fact, research supported the insurers' position; for example, the RAND Health Insurance Experiment found that mental health services were more responsive to patient cost-sharing than physical health (Newhouse et al., 1993). Economic theory dictates that optimal insurance policies feature less generous coverage for more elastically demanded services, such as mental health.

Two countervailing arguments were made by advocates of more generous mental health coverage. First, they stressed there would be significant "offset" effects: increased generosity of outpatient mental health coverage would reduce spending on inpatient mental health. While there is little evidence to support this claim, this was a strongly held belief in the Administration. Second, the development of managed health care limited the impact of cost sharing alone on mental health utilization. A health insurer with tight utilization management on mental health care could afford to reduce cost sharing on use of psychiatric services without worrying about significant cost increases.

After considerable debate, the Administration was able to secure passage of Public Law 104-204 in 1996, which prohibited health plans from establishing separate lifetime and annual limits for mental health coverage. The evidence since this legal change suggests that, consistent 
with the arguments above, plans did not spend much more on health care, as costs were managed in other ways.

A stronger step was an executive order, in 1999, mandating that all Federal Employees Health Benefit Program (FEHBP) plans have full mental health parity. This guaranteed benefit parity for all federal employees. The executive order was one example of a way that the Administration could avoid the pitfalls of dealing with a hostile Republican Congress on health issues: bypass Congress.

Other benefits mandates were passed as well, such as regulations stipulating that all women receive at least a two night stay in the hospital for childbirth. Once again, there is little evidence on the costs and benefits of these regulations.

A more important insurance debate was over the "Patients' Bill of Rights." Managed care grew rapidly in the 1980s and early 1990s, particularly after the demise of the HSA, as employers abandoned traditional fee-for-service insurance plans in favor of managed care. The rise of managed care drew increasing concern in public discussion. People worried that managed care would restrict access to necessary care. This was fueled by horror stories of patients being denied "necessary" care and being gravely injured as a result.

In fact, research suggests that such horror stories were not widespread. Quality of care in managed care plans, as best it can be measured, is virtually identical to quality of care in traditional indemnity plans (Miller and Luft, 1997). But the vast majority of people clearly felt otherwise. By the start of the second term of the Clinton Administration, the "managed care backlash" was in full swing.

To its credit (given the evidence), the Administration never really joined the managed 
care bashing full throttle. The Administration worried about managed care abuses but never went as far as many opponents of managed care hoped. Given the tenet of managed competition, with its emphasis on a diversity of health plans, bashing managed care at length would have been a large about-face.

The Administration's response to the managed care backlash was the establishment in 1997 of a "Quality Commission" that was charged with developing a patient's bill of rights. This bipartisan commission recommended that there should be guaranteed access to needed health care specialists; access to emergency room services when and where the need arose; continuity of care protections; and access to a fair, unbiased, and timely internal and independent external appeals process (Domestic Policy Council, 2001). These recommendations were immediately adopted by the Administration, setting off a fierce Congressional debate over patient protections that continues today. The major issue around which the current debate revolves is the right of patients to sue their HMOs for denial of care or other perceived abuses.

The Administration was unable to reach agreement in Congress. Instead, Congress slowly wound its way around this topic, with no agreement by the term's end. Perhaps as a result, Clinton left office with little progress on insurance restrictions, other than the HIPAA and using his executive powers to put some patient protections in place for FEHBP enrollees.

\section{Health Policy for the Elderly and Disabled}

Medicaid policy was essential to the children's health insurance expansion in 1997. But Medicaid is more than insurance for poor children and their moms. Two-thirds of Medicaid spending is for the elderly and disabled, paying for cost sharing Medicare does not and coverage 
Medicare omits, primarily prescription drugs and institutional long-term care. In this section, we discuss the evolution of Medicaid policy towards those groups during the Clinton years.

\section{Long Term Care Reforms}

After the failure of the HSA, which had a significant long-term care expansion, the administration took an incremental approach to long-term care. And, as with coverage initiatives for the non-elderly population, the record was mixed.

The Clinton Administration, like the Reagan and Bush Administrations before it, was interested in developing and promoting the private market for long term care insurance. Publicsector cost was the driving force; private long-term care insurance would be cheaper than public expansions. One of the few remnants of HSA that actually made its way into law was legislation in 1996 which gave employer-sponsored long-term care insurance the same tax preferred status that is conferred on employer-provided health insurance, while at the same time implementing basic quality standards that any tax-preferred product had to meet.

That this provision made it into law is not surprising, given the bipartisan support for taxinduced private coverage. Further, at the very end of its tenure, the Administration was also able to pass a proposal to introduce long term care products as a benefit for federal employees, with the hope that this would jump start the private employer market. Even with this legislation, though, the private long term care insurance market remains tiny, numbering no more than a few million policies. Employers burned by rising acute care costs for several decades do not appear eager to embark on the same path with long-term care.

Another potentially-important change of the Clinton years was the repeal of the Boren 
amendment that governed long term care reimbursement rates. This amendment, passed in 1980 allowed states to move to their own methodologies for reimbursing these providers, so long as rates were "reasonable and adequate". In the wake of a long history of lawsuits brought under the Boren amendment ruling that reimbursement rates were not reasonable and thus mandating higher payments, the amendment was repealed as part of the Balanced Budget Act of 1997. After BBA, states had only to provide public notice of their proposed rates for reimbursing hospitals, nursing facilities, and intermediate care facilities and the methods used to establish those rates. While this was viewed as a major victory for states, so far it has had little impact. Medicaid rates for nursing homes have risen at roughly the same rate since the repeal as before, and there has not been any concerted movement among the states to more restrictive nursing home payment methodologies..$^{10}$

By far the most expansive post-HSA effort on long-term care came late in the Administration, with the proposal of a tax break for those with long-term care needs and their caregivers. The initiative was developed after the 1997 BBA enacted many new benefits for children, including tax breaks for the cost of college education, and the CHIP expansion. But these policies did the elderly and near elderly little good. Long-term care (and prescription drug coverage) would rectify this potential political oversight.

Long term care costs are very high for a relatively small number of persons. Insurance principles argue for covering this population first. But past experiences with incremental approaches had convinced administration officials that they needed a broad base of support for a new policy. This required benefits at a lower level of spending. The compromise was to provide a credit of modest size, $\$ 3,000$, that would apply to any person, or their caregiver, who was 
somewhat but not totally disabled (defined as having three or more activities of daily living, or ADLs). In addition, a proposal was made for tax deductibility for private expenditures on long term care insurance, to complement the deductibility of employer spending passed in 1996. Even this somewhat broad proposal, however, found very little public support, and it did not become law.

Finally, the Administration actively pursued regulatory changes to improve long term care. One such change was growing endorsement of state Medicaid waivers for the provision of home and community-based care for the elderly and disabled. Spending on these waivers rose from \$2.2 billion in FY 1992 to $\$ 10.6$ billion in FY 1999. In theory, states must show that these waivers pass cost-effectiveness tests before they can be approved by HCFA, in terms of offsetting increased community care costs with lower institutionally-based care costs. In practice, it seems unlikely that they can meet these cost effectiveness standards, given the existing (albeit dated) evidence on the subject. The Channelling experiment of the 1970s randomly assigned to some families more exhaustive community based care; but, while this improved quality of living, it had no impact in terms of reducing institutionally-based care use (Kemper, 1988). A second initiative, pursued at the very end of the Administration's tenure, was an aggressive campaign to improve nursing home quality through the Medicare and Medicaid programs.

\section{Policy for the Disabled}

Incremental, but meaningful, accomplishments were made in policy for the disabled. Fewer than one percent of receipients return to work after starting on disability insurance (DI) 
(U.S. General Accounting Office, 1998). One barrier to returning to work is the high cost of health insurance, leading to a reluctance to drop the public Medicare entitlement that comes with enrollment in disability insurance (after two years). The Jeffords-Kennedy Work Incentives Improvement Act, passed in 1999, addressed this problem by extending Medicare coverage for another $4 \frac{1}{2}$ years after someone leaves the Disability Insurance (DI) program; the law also allowed some disabled not on the program to buy into their state's Medicaid insurance pool.

This law is an example of where the incremental approach to health reform was both a policy and political success. It is eminently sensible to extend incentives to work for a population receiving many other benefits: in the worst case, the policy has no effect and no cost; in the best case, it saves money overall by inducing the disabled to work. In political terms, by addressing such a clearly needy population, and at such a low cost, the law was hard to resist.

\section{Tobacco Policy}

As is reflected in the discussion thus far, the primary focus of the Administration's health policies was on health insurance coverage and market reforms. This reflects a basic view among Administration officials, shared by many health care analysts, that health insurance coverage was the primary policy tool available for improving the health of the U.S. population. But this view is not universal. Many prominent observers suggest that medical care is a secondary influence on health relative to individual decisions to engage in healthy, or unhealthy, behaviors (e.g. McGinness and Foege, 1993). ${ }^{11}$

Perhaps the most widespread unhealthy behavior in the U.S. population is smoking. An aggressive public information campaign has led to a massive, three decade-long decline in 
smoking in the U.S. Still, more than a fifth of the adult population continues to smoke. Smoking is the largest cause of preventable illness in the U.S., accounting for more than 400,000 deaths per year, more than AIDS, alcohol, cocaine, heroin, homicide, suicide, motor vehicle crashes, and fires combined (U.S. Department of the Treasury, 1998). The typical smoker's life expectancy is about 6 years less than if they did not smoke (Cutler et al., 2000).

There were two new elements in the Clinton Administration. The first was the rise in youth smoking. Beginning in 1993, youth smoking ended a long period of decline and began a sustained increase. As shown in Figure 4, by 1997, youth smoking had risen by roughly onethird from its 1992 trough, before declining again after 1997 (due to price increases that are discussed below).

Three-quarters of smokers start as youths (Gruber and Zinman, 2001), so increasing youth smoking initiation could reverse the recent trend towards lower overall cigarette usage. Moreover, youths have demonstrated a clear lack of appreciation for the addictive nature of their smoking habit. Among high school seniors who smoke, 56 percent say that they will not be smoking five years later, but only 31 percent of them in fact quit within five years. Moreover, among those who smoke more than one pack/day, the smoking rate five years later among those who stated that they would not be smoking ( 74 percent) is actually higher than the smoking rate among those who stated that they would be smoking (72 percent) (U.S. Department of Health and Human Services, 1994).

The second factor was the shift of tobacco companies from a business like any other, and thus not deserving of special government punishment, to a pariah among business over deceptive advertizing and attempts to hook youths. The emergence of the "Joe Camel" campaign, and the 
negative public reactions to it as an obvious attempt to woo young smokers, was a symbol of this transition in public perceptions.

Of course, from an economics perspective, the fact that smoking is inherently harmful is not justification for regulating or taxing it. In the standard economics paradigm, the only justification for regulating or taxing an activity is the externalities it causes to others; damage to self is presumed to be incorporated into the rational decision to smoke. And the externalities from smoking may be quite low, as much of the health care cost increases of smoking appear to be offset by savings to the Social Security program and other defined benefits pensions from early mortality. Gravelle and Zimmerman (1994) estimated the net externalities of smoking at only 33 cents per pack, although this estimate ignores potentially important factors such as second hand smoke and long term health consequences of low birthweight babies (Gruber, 2001b). This level of externalities was actually lower than the actual tax per pack of cigarettes when the Clinton Administration took office.

Of course, this "rational addiction" model is not readily accepted outside of economics. Even within formal economics, recent analyses have suggested alternatives for moving beyond this formulation in thinking about optimal taxation of addictive bads such as cigarettes (Gruber and Koszegi, 2000; Laux, 2000). Considerations such as the underprediction of addiction for teens, the fact that adults express strong desires to quit smoking but seem unable to, and the popularity of "self control" devices such as self-imposed punishments for continuing to smoke, all point to alternative models with "time inconsistent" consumers who do not fully appreciate the future consequences of their actions. In such a situation, the fact that smoking harms one's own health can be a rationalization for government action, as government regulation acts as the 
type of "self control device" craved by smokers who cannot quit even though they would like to do so over the long run. This becomes an important consideration because, while the externalities of smoking may be low, the "internalities" (or damage to self) are enormous; the costs per pack of cigarettes through increased mortality alone is $\$ 30$ per pack using standard estimates of the value of a life (Gruber and Koszegi, 2000). Estimates such as those in Gruber and Koszegi (2000), who compute an internality correction tax of $\$ 1.00$ for even very modest time inconsistency, suggest that taxes were indeed too low in the early 1990s.

Public policy towards smoking had been stymied for years by the profitable and wellconnected tobacco companies. As a result, beyond informational campaigns, there had been little effective increase in government regulation of this industry since the 1960s. Indeed, by 1995 , real federal and state excise taxes on cigarettes were one-third below their peak level of the mid1960s.

The Administration ultimately took on the tobacco industry, haltingly at first, and with vigor later on. Anti-tobacco policy became a significant accomplishment of the Administration, despite the lack of legislative actions. The social actions in isolating tobacco companies and focusing attention on youth smoking could have significant long-term benefits for public health.

\section{Early Initiatives}

The Administration made tobacco taxes part of its agenda early on, with a proposed 75 cent rise in the federal excise tax on cigarettes as part of the HSA. By comparison, the federal tax at that point was 24 cents. The tobacco tax was the only explicit tax in the proposal. But the rhetoric was not explicitly punitive. Rather, smoking was an obvious target because it cost 
money and lives, and some revenues were needed for the HSA. The Administration actually rejected a higher tobacco tax in formulating its plan, for fear of antagonizing tobacco state Democrats. Of course, when the HSA was defeated, this tax was not passed. Tobacco taxation reemerged as a source of insurance expansion funding in 1997, and a 15 cent increase in tobacco taxation in the BBA 97 was a source of funding for CHIP.

The real driving force for substantial tobacco regulation in the first Clinton term was not the White House or Democratic political operatives, but rather FDA Commissioner David Kessler (Kessler, 2001). Early in his and the Administration's tenure, Kessler decided to push the envelope of what the FDA might do in terms of regulating tobacco, a topic of interest but little action for previous FDA regimes. Kessler's charge led to the announcement in August 1996 of the nation's first comprehensive program to prevent children and adolescents from using cigarettes or smokeless tobacco. This program would mandate proof of age 18 for tobacco purchase; cigarette vending machines would be banned from locations frequented by children such as supermarkets; tobacco advertising on billboards near schools and playgrounds would be forbidden; all billboards advertising tobacco would be printed in black and white and contain no pictures; and tobacco companies would be forbidden from aiming their marketing campaigns at young people and within two years would be banned from sponsoring sporting events.

In March of 1997, the FDA regulation requiring retailers to have all tobacco customers up to age 27 prove that they are at least 18 years old went into effect. The FDA then planned to implement the regulations pertaining to tobacco advertisements over the next six months, but in April of 1997, a Federal judge in North Carolina ruled that the FDA could not control tobacco advertising aimed at young people. However, the judge also ruled that the 
FDA could regulate cigarettes as drugs, giving the FDA the potential to control nicotine levels in cigarettes. The FDA was collecting data on the effects of varying nicotine levels when a Federal Appeals Court ruled that the FDA lacked the authority to regulate cigarettes or smokeless tobacco in 1998. In March of 2000, the Supreme Court also ruled that the FDA did not have the authority to regulate tobacco as an addictive drug in a 5-to-4 decision.

\section{Litigation $^{12}$}

The next round of battle over tobacco was fought early in the second term, and once again the genesis was not the Administration, but rather state Attorneys General and the industry itself. There was a long history of private individuals suing the tobacco industry for premature morbidity and mortality, dating back to 1954 . Historically, the tobacco industry had won every legal case it faced, with the single exception of a $\$ 400,000$ judgement against the Liggett group that was overturned on appeal. The failure of individual's suits was often because it was difficult to tell for any given death whether the case was smoking-related or due to some other factor (cigarette smokers often don't exercise, for example).

Clever lawyers decided to counter this by suing as a group. Thus, no individual death need be attributed to tobacco, only deaths on average. In 1994, the first class action lawsuit was filed against the industry in Castano et al. v. The American Tobacco Company. Sixty-five law firms pooled their resources to file this case, which alleged that the tobacco industry had failed to warn adequately about the addictive properties of cigarettes. This suit was ruled too unwieldy by the Fifth Circuit Court of Appeals in 1996, perhaps reflecting the difficulty of pursuing these 
types of class actions across state lines given very different state regulatory guidelines (Bulow and Klemperer, 1999). But it set the stage for the state lawsuits to follow.

On March 23, 1994, the state of Mississippi filed a lawsuit against the tobacco industry to recover the costs to the state of treating smoking-related illness under its Medicaid program. No state had ever attempted such litigation before. This lawsuit posed two particular problems for the industry (Bulow and Klemperer, 1999). First, it relied on the argument that the industry was liable to the state for medical costs, even if smokers knowingly contributed to their illness. Thus, individual decisions to smoke were less relevant. Second, it was filed shortly after the passage of Florida's Medicaid Third-Party Liability Act of 1994 (and the consideration of similar legislation in other states), which allowed the state to sue a manufacturer of an allegedly harmful product for the medical expenses of a group, relying on statistical evidence instead of proving causation and damages in each case. Tobacco litigation was the first application of this.

In the wake of the Mississippi suit, most other states filed similar suits for Medicaid cost recovery. Under pressure, the largest "fringe" manufacturer, Liggett, broke ranks with the major industry participants in early 1996 to settle with five states, in the process providing a host of secret documents that detailed industry knowledge of the damages of smoking and marketing to youth. These 'smoking gun' documents provided further ammunition for additional cases and account for a significant change in the public's perception of the tobacco industry. The legal risks from state and private class action suits were an enormous drag on the market value of the industry; indeed, Bulow and Klemperer (1998) reported that the implicit market value of the domestic tobacco side of RJR Nabisco had become roughly zero in the mid-1990s. 
In the face of this enormous legal risk, the tobacco industry sat down early in 1997 with the Attorneys General of the states filing lawsuits and the lawyers behind the Castano class action suit to attempt to hammer out a comprehensive agreement. In April 1997, a proposed settlement was announced. The key components were that the industry would agree to pay $\$ 368$ billion over 25 years to the states, in return for: a) dismissing the state suits; b) immunity from future punitive damages as part of individual suits; and c) immunity from future class action suits. In effect, this industry was buying legal peace. The financing of the payments was largely through taxation, although this was not directly stated. A key component of the payments was a "volume adjustment" that would tie each company's payment to its volume of cigarette sales. This in effect converted the settlement into a tax (with the exception of a $\$ 10$ billion up-front payment), as both linked payments to sales, and all evidence suggests that past taxes on tobacco had been fully passed on to prices, so that this "settlement" would be as well. ${ }^{13}$ Bulow and Klemperer (1998) calculate that, given the inelasticity of demand for cigarettes, the industry could pass this tax on to prices and suffer only a $\$ 1$ billion per year reduction in profits while transferring $\$ 13$ billion per year to the states. ${ }^{14}$

While the Attorneys General had the right to settle their state lawsuits, the approval of Congress was needed to grant other legal immunities. It was at this point that the White House became involved.

\section{The Administration Acts}

In September 1997, the Clinton administration announced that it was not satisfied with the parameters of this tobacco deal and would not endorse legislation to implement it. The key 
concern was that the payments were not large enough. It had not escaped the Administration's notice that tobacco stock prices jumped significantly on the day the deal was announced, and Wall Street analysts suggested that the enormous discount at which tobacco stocks had historically traded relative to comparable investments would disappear under this deal. In addition, there were concerns about restrictions in FDA jurisdiction over tobacco and other perceived weaknesses.

In spring 1998, the Clinton administration worked with Senator John McCain and others to develop a legislative alternative to the Attorneys General settlement. This alternative differed in a number of key ways from the original settlement. First, there was a much larger payment $\$ 516$ billion over 25 years compared to $\$ 368$ billion. Second, the Food and Drug Administration (FDA) was given full regulatory authority over tobacco products, as it has over other pharmaceuticals and medical drugs. Third, regulations on youth smoking were increased, including greater enforcement of youth access restrictions, and a very sizeable "youth lookback penalty" which imposed both industry-wide and company-specific payments if youth smoking did not decline in the future. Finally, the legal protections provided against private lawsuits were more limited, although the state suits were settled in full. Due in part to limitations on legal protections designed to woo key Democrats, the proposed legislation was voted almost unanimously out of the Commerce Committee in the Senate. But, after several weeks of debate, it died on the floor of the Senate in June of 1998.

The demise of tobacco legislation is interesting in comparison to the experience of the HSA. The Administration clearly learned from its HSA experience. There was constant caution about getting ahead of the Congress on the issue, and a genuine effort to work in a bipartisan 
fashion with Senator McCain. But still, a consensus could not be formed. The bill could not pass Congress with anything approximating the legal protections on future lawsuits of the original Attorney's General settlement. Indeed, during floor debate the remaining protections were actually stripped out. This, in turn, turned the tobacco industry from ally to opponent, leading to the bill's demise.

Tobacco regulation did not fail because it was too Democratic, because it was drafted in secret, or any of the other arguments made about the HSA. It failed rather because it was too big and did not offer enough benefits to the tobacco industry. It is simply too hard to undertake such ambitious legislation in today's political climate. Perhaps this is what happened to the HSA as well.

After the demise of the tobacco legislation, the industry and states went back to the negotiating table. A more limited settlement was hammered out in November 1998. Under this Master Settlement Agreement (MSA), the industry would pay \$206 billion to the states over 25 years, the equivalent of roughly 45 cents per pack; Cutler et al. (2000) calculate that the PDV of these payments was $\$ 105$ billion through the year 2025. The MSA also included some voluntary advertising restrictions, such as the removal of billboard advertisements for cigarettes, and a ban on using cartoon characters in advertisements. There was no restriction on private litigation.

The individual state settlements, the Master Settlement Agreement, and the proposed McCain bill all shared some important limitations, which are highlighted by Bulow and Klemperer (1998). First, these approaches provide contracts only with the major tobacco producers and leave other brands without an obligation to make payments. This provides a substantial cost advantage for these other brands (which make up only a few percentage points of 
the market, at least at the time of this deal), conferring a windfall profit on them. These windfall profits are capped by a feature of the MSA -- the "non-participating manufacturers adjustment" -that essentially mandates that states levy taxes on any sales of non-participating manufacturers that exceed 125 percent of their 1997 market share; if states do not pass such taxes, they risk losing most or all of their state payments (Cutler et al., 2000).

A second area of concern is the enormous payments going to lawyers from this settlement. Under the Master Settlement Agreement, lawyers representing the 46 settling states received $\$ 1.25$ billion initially and $\$ 500$ million per year thereafter. These payments appear disproportionate to the actual work done by lawyers in many states, some of whom had not even filed cases before the MSA was signed. Jeremy Bulow estimated that the lawyers fees based on the actual damage payments would have been about 1/40th of the actual payments they are scheduled to receive (Nasar, 1998).

The way to solve both of these problems would be with a straight-out tax increase rather than a complicated settlement. Such a tax increase would certainly be better social policy. But the outlook for a tax increase was poor. The indirect taxation of the settlement was really the only option. In this sense, the payments to lawyers and excess profits to small producers, while inequitable, can be viewed as the political economy costs that must be paid to impose cigarette taxes.

The tobacco industry responded to the MSA by raising prices. In fact, price increases in 1997 and 1998 exceeded the amount required to pay the costs of state settlements by roughly 2025 cents per pack (Black, 1998). A price increase this large, given the highly inelastic demand for cigarettes, would imply that tobacco industry profits actually rise as a result of the settlement, 
as the profit lost from the relatively small declines in sales is more than offset by the additional profit earned on the remaining packs sold. This excessive rise in prices was also a feature of the industry's reaction to previous federal tax increases; Harris (1997) suggests that the tobacco companies may use these events as focal points to achieve higher industry-wide prices, a story of implicit collusion. Another (perhaps complementary) explanation may be that the industry was convinced in the wake of its failed attempt at a comprehensive settlement that the domestic tobacco industry was in rapid decline, so that its past strategy of keeping prices low to induce new smokers to take up the habit is no longer worthwhile.

The fact that prices rose above settlement costs raises a central tension in tobacco control policy (and one which was never really fully resolved inside the Administration): is the goal to punish the managers or shareholders in tobacco companies, or to raise cigarette prices and thereby discourage smoking? If the former, then the MSA or the equivalent excise tax would not have the desired effect. If the latter, the additional price increase is a positive outcome of the settlement.

Despite this settlement, however, the industry's legal woes are far from over. In 1997, Lorillard paid over $\$ 1.5$ million to the family of Morton Horowitz, the first time a U.S. cigarette maker had ever paid a smoking-related personal injury claim. The industry paid out $\$ 350$ million in the Broin case to airline attendants who had illness claims related to secondhand smoke exposure. The tobacco industry has also lost several other high profile cases in recent years, culminating in the Engle case in Florida in July 2000, in which a jury awarded a class of 500,000 smokers in Florida $\$ 145$ billion in damages. These payments are lump sum and not subject to future sales of cigarettes, so incorporation into prices may not be so immediate. While all of 
these recent decisions remain subject to appeal, the past invulnerability of the industry to private lawsuits is clearly being penetrated. New information about the tobacco industry has clearly affected its public image.

Finally, in September 1999, the U.S. Department of Justice filed suit against the industry to recover the costs to the federal government of smoking-related illness. According to the complaint, the costs of smoking to the Medicare, Veteran's Administration, and Federal Employees Health Benefit Program amount to more than $\$ 20$ billion per year. The complaint also seeks additional damages under a racketeering charge against the industry, resulting from its (alleged) conspiracy since the early 1950s to defraud the American public about the dangers of smoking. But the courts have so far rejected the medical costs part of this claim, and outlook for this case under the watch of the Bush Administration is unclear.

\section{Summary}

Despite the failure of comprehensive legislation, the efforts of the Clinton Administration had enormous impacts on tobacco policy. The 15 cent rise in the tobacco excise tax in BBA 97 was the first major increase in federal tobacco taxation in 15 years. And, while the Administration was not able to craft an alternative to the original Attorney's General settlement, it did reject a deal which was likely too soft on the industry. The result was a major settlement of just the state suits, and ongoing legal woes for the industry.

And perhaps more important, the tide has turned against the tobacco industry. The public is outraged about past behavior and private lawsuits are increasingly leading to price increases, deterring future smokers. The industry is no longer invincible. 
Looking forward, the federal government faces two possible paths in terms of regulating the tobacco industry. The first is to sit back and let the lawsuits proceed -- both private lawsuits and those of the U.S. Department of Justice. The disadvantage of this approach is that the tort system is a haphazard and inefficient mechanism for reducing tobacco use, with large deadweight losses and uncertain outcomes. ${ }^{15}$ Moreover, if the existing industry participants are pushed into bankruptcy, the market may pass to new companies who do not face such enormous legal liabilities from past poor conduct.

At the other extreme, the government can act legislatively, providing the industry with the kind of legislative shield against legal risk that it sought through the proposed 1997 Attorneys General settlement, perhaps in return for some level of payment and tighter regulation of tobacco products. But providing a legal shield for the industry is a risky strategy as well. There is enormous uncertainty about the "optimal" cigarette price that would capture accurately at least the externalities -- and perhaps also some of the internalities -- of smoking. In addition, the federal government does not have an enviable track record for regulating this industry, and once the lobbying begins, there is some risk that the tobacco companies would get off very easy. A tradeoff that involves settlement of current lawsuits but no new lawsuits would also be inequitable for smokers who have not yet brought smoking-related claims. This could set a disturbing precedent, if future corporations see a possibility of avoiding tort liability by signing government agreements. 


\section{Other Public Health}

Tobacco was not the only area of activity for the Administration in the public health arena. We group as our last set of policies a series of public health actions enacted throughout the Administration, but particularly in the latter half. Several policies fall under this rubric. They include: substantially increased funding for childhood vaccinations (beginning in 1993) and encouraging outreach efforts to find children needing immunization; increased funding for HIV prevention and treatment, including the Ryan White Care Act, which funds HIV and AIDS care for poor and uninsured people; agreement with Congress in 1998 to double the NIH budget (at the time, about $\$ 15$ billion per year) over the course of five years; requiring more reporting of medical errors and mandating error reduction programs in hospitals; and increased funding for and coordination of community care clinics serving the uninsured.

In addition, the President used his bully pulpit to call attention to health issues that had not been high profile. These include: women's health, including family planning and reproductive health; mental health, including a White House conference and the first Surgeon General's report on the topic; and racial and ethnic disparities in health, including setting as a goal for Healthy People 2010 the elimination of racial and ethnic disparities in health.

It is too soon to evaluate most, if not all, of these policies. Public health changes improve health over a span of decades, not years. For example, the Surgeon General first warned of the dangers of smoking in 1964. Over the next quarter century, smoking rates declined in half. If repeated reports from the Surgeon General about mental health lead to a change in mental health care and behavior of anywhere near that magnitude in the next quarter century, this will rank as one of the single greatest actions of the Clinton Administration. 
These initiatives had several features in common. First, they each responded to a particular public health need or concern and kept the focus on that one issue. For example, the requirement that hospitals report medical errors was a direct response to a National Academy of Sciences report on the high rate of errors in hospital practice. But rather than using the occasion to begin a major program of hospital auditing or error detection, the Administration settled for the smaller, easier policy of requiring reporting of medical errors. As a result of this small focus, these policies were easy to justify. To a public seeing on the evening news stories about medical errors and hearing a report estimating thousands of deaths from such errors, it was straightforward to accept targeted actions to reduce errors.

Second, the policies are generally cheap. Even the most expensive of these programs, the doubling of the NIH budget, cost about $\$ 10$ billion dollars per year, not the $\$ 60$ to $\$ 70$ billion of a major coverage expansion. The universal vaccine program for children cost only $\$ 1$ billion. Third, the policies often help with an overall goal of increasing insurance coverage and reducing medical care costs, but they do not form any natural bridge from here to there. Consider again the policies about reducing medical errors. Medical errors are costly; reducing errors would reduce overall medical care costs. But this factor is small in relation to the overall increase in medical care costs over time. It is difficult to imagine any big changes in overall medical care spending (and thus overall rates of insurance coverage) from such legislation.

\section{Conclusions}

In health care, the Clinton Administration will be remembered most readily for a spectacular failure - the Health Security Act. Less well known will be a series of other, 
oftentimes successful policies: coverage expansions for children, changes in long-term care and care for the disabled, and a dramatic change in the public's view of cigarettes. Our recall of the Clinton Administration in years hence should include these successes as well.

Still, a lot of health care work remains. The Clinton Administration wanted to expand access to insurance, make the middle-class feel safe, and control the costs of medical care. The private market took care of the last of these goals, at least for a few years. There are indications that health care costs are beginning to increase again. While policymakers might once have viewed these changes as adverse, the new view that cost increases in medical care represent the expansion of valuable technology to more people (Cutler and McClellan, 2001) reduces a lot of concern about rising health costs.

Policy did a little, but not much, on making the middle class feel safe. The Federal government, along with state governments, tried to regulate what insurance companies could do. But success was limited. Fundamentally, people felt safer in their health insurance at the end of the Clinton Administration because they felt safer in their jobs. When job safety declines, so will confidence in having health insurance.

The private sector did very little at the last goal, increasing insurance coverage. Despite the best economy in generations, the share of people without insurance coverage rose. Our personal forecast is that this trend will have a major impact on public policy over the next decade and beyond. We have learned that the private sector will not guarantee insurance coverage to the vast majority of the uninsured. Unfortunately, we have also learned that the political process is not particularly willing to deal with the issue either. Where that leaves policy in coming years is not entirely clear. 


\section{References}

Becker, Gary S., and Kevin Murphy (1988). “A Theory of Rational Addiction,” Journal of Political Economy, 96, 675-700.

Black, Gary (1998). "Big Price Increase: Early Trade Liquidation Should Lower 1998, Raise 1999 Estimates," report available at www.tobacco.org/news/Blackf/981124black.html.

Blendon, Robert J., "Mollyann Brodie, and John Benson (1995), "What Happened to Americans' Support for the Clinton Health Plan?", Health Affairs, 14(2), Summer, 7-23.

Broaddus, Matthew, and Leighton Ku (2000). "Nearly 95 Percent of Low Income Children are Now Eligible for Medicaid or SCHIP”. Washington, DC: Center on Budget and Policy Priorities.

Bulow, Jeremy, and Peter Klemperer (1998). "The Tobacco Deal," Brookings Papers on Economic Activity: Microeconomics, 323-394.

Cooper Philip, and Barbara Schone (1997), "More Offers, Fewer Takers for Employment-Based Health Insurance: 1987 and 1996", Health Affairs, 16(6), November/December, 142-149.

Currie, J. and J. Gruber (1996a). "Saving Babies: The Efficacy and Cost of Recent Expansions of Medicaid Eligibility for Pregnant Women," Journal of Political Economy, 104, 1263 1296.

Currie, Janet, and Jonathan Gruber (1996b). "Health Insurance Eligibility, Utilization of Medical Care, and Child Health," Quarterly Journal of Economics, 111, 431-466.

Cutler, David M. (1994a), “A Guide to Health Care Reform”, Journal of Economic Perspectives, Summer, 3-17. 
Cutler, David, "Market Failure in Small Group Health Insurance" (1994b), mimeo.

Cutler, David M., "Technology, Health Costs, and the NIH", National Institutes of Health Roundtable on the Economics of Biomedical Research, 1995.

Cutler, David, "Health Care and the Public Sector" (2001), forthcoming in Alan Auerbach and Martin Feldstein, eds., Handbook of Public Economics, Volume 3, Amsterdam: Elsevier.

Cutler, David, and Jonathan Gruber (1996). "Does Public Insurance Crowd Out Private Insurance?," Quarterly Journal of Economics, 111, 391-430.

Cutler, David, and Brigitte Madrian (1998). "Labor Market Responses to Rising Health Care Costs," RAND Journal of Economics.

Cutler, David, and Mark McClellan (2001), "Is Technological Change in Health Care Worth It?", mimeo.

Cutler, David, Jonathan Gruber, Raymond Hartman, Mary Beth Landrum, Joseph P. Newhouse, and Meredith Rosenthal (2001). "The Economic Impacts of the Tobacco Settlement," forthcoming in Journal of Policy Analysis and Management.

Domestic Policy Council(2001). "Health Care Accomplishments of the Clinton Administration,". Washington, DC: The White House.

Employee Benefits Research Institute (2000). "Sources of Health Insurance and Characteristics of the Uninsured". Washington, DC: EBRI.

Farber, Henry, and Helen Levy (2000), "Recent Trends in Employer-Sponsored Health Insurance Coverage: Are Bad Jobs Getting Worse?," Journal of Health Economics, 19(1), 93-119. 
Feldman, Roger, and Bryan Dowd (1993). "The Effectiveness of Managed Competition in Reducing the Costs of Health Insurance", in Robert Helms, Health Policy Reform: Competition and Controls, Washington, D.C.: American Enterprise Institute, 176-217.

Fuchs, Victor, "Comment on Cutler and Gruber", this volume.

Gravelle, Jane and D. Zimmerman (1994). "Cigarette Taxes to Fund Health Care Reform: An Economic Analysis," Congressional Research Service Publication 94-214E. Washington, D.C: Library of Congress.

Gruber, Jonathan (1994). "The Incidence of Mandated Maternity Benefits," American Economic Review, 84:622-641.

Gruber, Jonathan (1997). "Health Insurance for Poor Women and Children in the U.S.: Lessons from the Past Decade," in Tax Policy and the Economy 11, James Poterba, ed.

Cambridge, MA: MIT Press, 169-211.

Gruber, Jonathan (2000). "Medicaid," forthcoming in Robert Moffitt, ed., Means Tested Transfer Programs in the U.S.

Gruber, Jonathan (2001a). "Health Insurance and the Labor Market," in Joseph Newhouse and Anthony Culyer, eds., The Handbook of Health Economics. Amsterdam: North Holland, p. 645-706.

Gruber, Jonathan (2001b). “Tobacco at the Crossroads: The Past and Future of Smoking Regulation in the U.S.," Journal of Economic Perspectives, forthcoming.

Gruber, Jonathan, and Botond Koszegi (2000). "Is Addiction 'Rational'? Theory and Evidence," NBER Working Paper \#7507, January 2000 
Gruber, Jonathan, and Larry Levitt (2000). “Tax Subsidies for Health Insurance: Costs and Benefits," Health Affairs, 19, p. 72-85.

Gruber, Jonathan, and Brigitte Madrian (1996). "Health Insurance and Early Retirement:

Evidence from the Availability of Continuation Coverage," in David Wise, ed., Advances in the Economics of Aging. Chicago: University of Chicago Press, p. 115-143.

Gruber, Jonathan and Robin McKnight (2001). "Why are Employee Health Insurance Contributions Rising,” mimeo, MIT.

Gruber, Jonathan, and Jonathan Zinman (2000). Youth Smoking in the U.S.: Evidence and Implications," in Jonathan Gruber, ed., Risky Behavior Among Youth: An Economic Analysis. Chicago: University of Chicago Press, p. 69-120.

Harris, Jeffrey (1987). "The 1983 Increase in the Federal Cigarette Excise Tax," in Lawrence Summers, ed., Tax Policy and the Economy. Cambridge, MA: MIT Press, p. 87-112. Institute of Medicine (1985), "Preventing Low Birth Weight”, Washington, D.C.: National Academy Press.

Kessler, David, A Question of Intent : A Great American Battle With A Deadly Industry, New York: Public Affairs, 2001.

Laux, Fritz (2000). “Addiction as a Market Failure: Using Rational Addiction Results to Justify Tobacco Regulation,” Journal of Health Economics, 19, p. 421-438.

Madrian, Brigitte C. 1994. "Employment-Based Health Insurance and Job Mobility: Is There Evidence of Job-Lock?," Quarterly Journal of Economics 109, 27-51. 
McGinnis, J. Michael, and William H. Foege, (1993), “Actual Causes of Death in the United States." Journal of the American Medical Association, 270(18), November 10, :2207-2212.

Miller, Robert H., and Harold Luft (1997), “Does Managed Care Lead to Better or Worse Quality of Care?", Health Affairs, 16, 7-25.

Nasar, Sylvia (1998). "The Ifs and Buts of the Tobacco Settlement," New York Times, November 29, 1998, Section 4, p. 1.

Newhouse, Joseph (1992), “Medical Care Costs: How Much Welfare Loss”, Journal of Economic Perspectives, 6(3), Summer, 3-21.

Newhouse, Joseph et al. (1993). Free for All? Lessons from the RAND Health Insurance Experiment. Santa Monica, CA: RAND Corp.

Nichols, A., and Richard Zeckhauser (1982). "Targeting Transfers Through Restrictions on Recipients," American Economic Review, 72, 372-377.

Nichols, Len, and Linda J. Blumberg (1998), “A Different Kind of New Federalism? The Health Insurance Portability and Accountability Act of 1996", Health Affairs, 17(3), May/June, $25-42$.

Orszag, Jonathon, Peter Orszag, and Laura Tyson (2001), “The Process of Economic Policy Making During the Clinton Administration", chapter for this volume.

Peden, Edgar A., and Mark S. Freeland (1995), “A Historical Analysis of Medical Spending Growth, 1960-1993", Health Affairs, 14(2), Summer, 235-247.

Pollitz, Karen, Nicole Tapay, Elizabeth Hadley, and Jalena Specht (2000), "Early Experience With 'New Federalism' In Health Insurance Regulation”, Health Affairs, 19(4), July/August, 7-22. 
Sheiner, Louise (1999), "Health Costs, Aging, and Wages", mimeo, Federal Reserve Board.

Summers, Lawrence H. (1989), "Some Simple Economics of Mandated Benefits", American Economic Review, Papers and Proceedings, 79(2), May, 177-183.

U.S. Department of Health and Human Services (1994). Preventing Tobacco Use Among Young People: A Report of the Surgeon General. National Center for Chronic Disease Prevention and Health Promotion. Office of Smoking and Health.

U.S. General Accounting Office (1998). Social Security Disability Policy: Factors Affecting Beneficiaries' Return to Work. Testimony before the Subcommittee on Social Security and Family Policy, Committee on Finance, U.S. Senate, July 29, 1998.

Zwanziger, Jack, and Glenn A. Melnick (1998). "The Effects of Hospital Competition and the Medicare PPS Program on Hospital Cost Behavior in California", Journal of Health Economics, 7, 301-320. 
Figure 1: Share of Non-Elderly Population Without Health Insurance

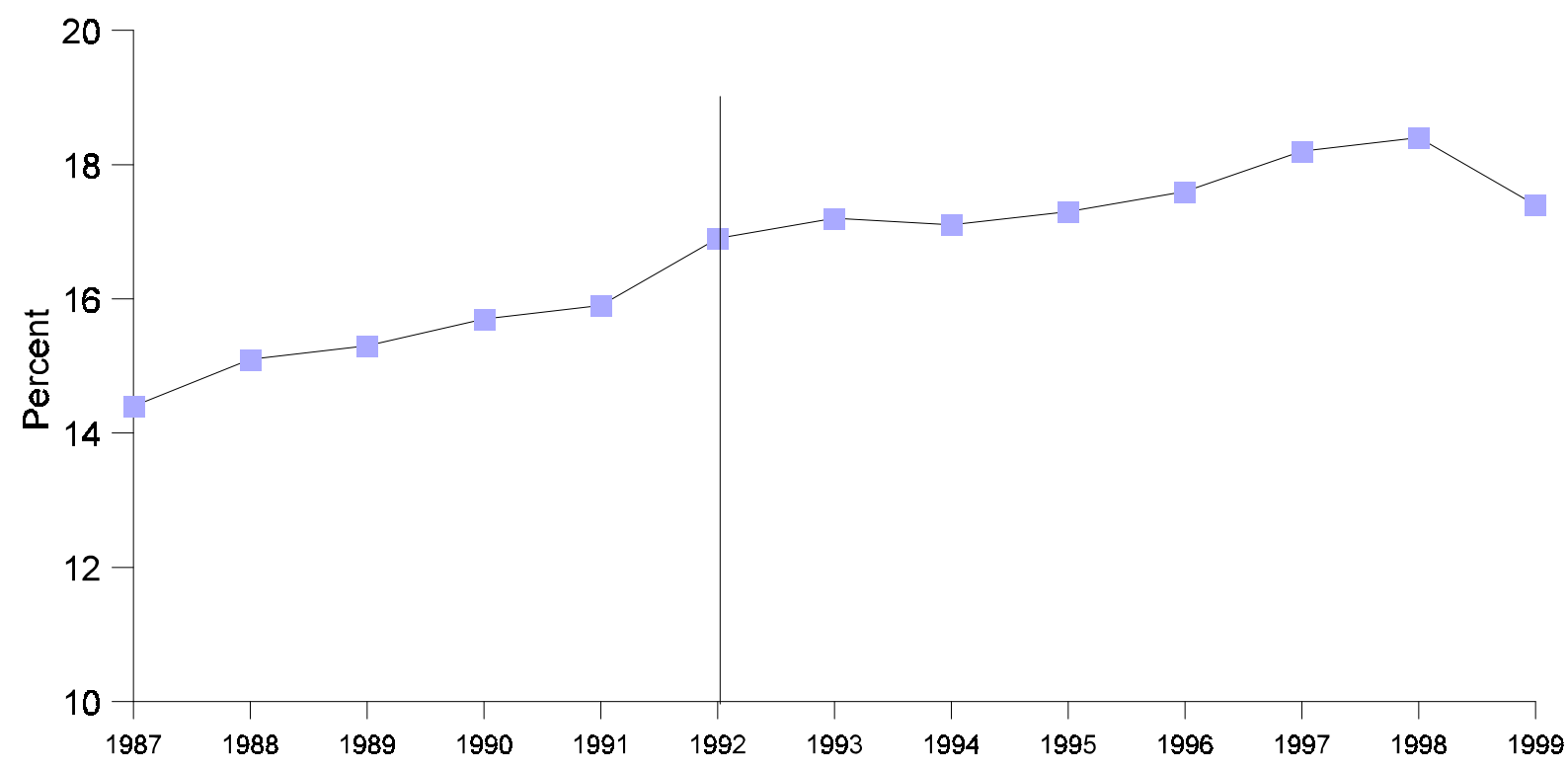

Note: Data are from the Current Population Survey. 
Figure 2: Insurance Coverage by Income, 1990

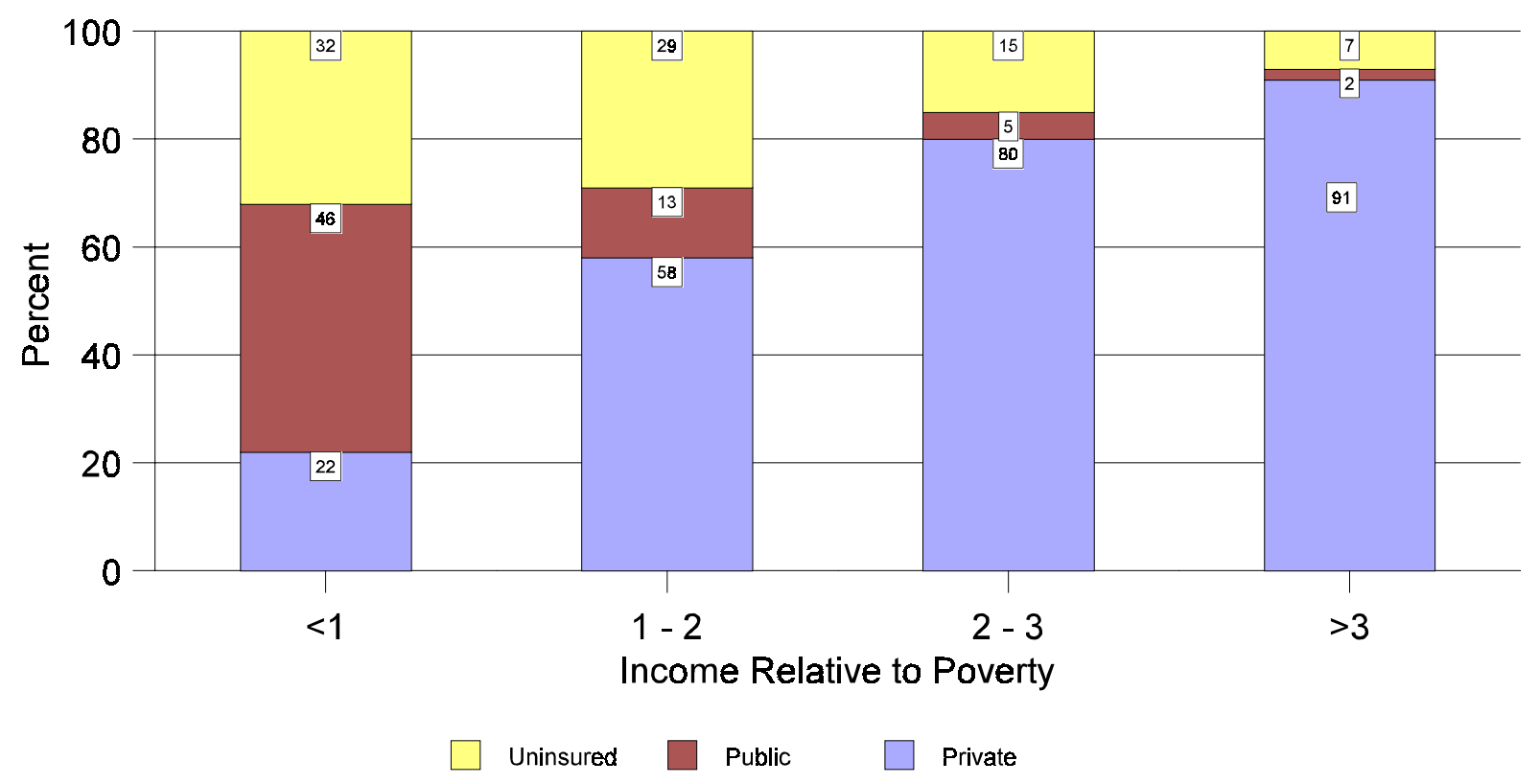

Note: Data are from the March 1991 Current Population Survey. 
Figure 3: Real Medical Spending

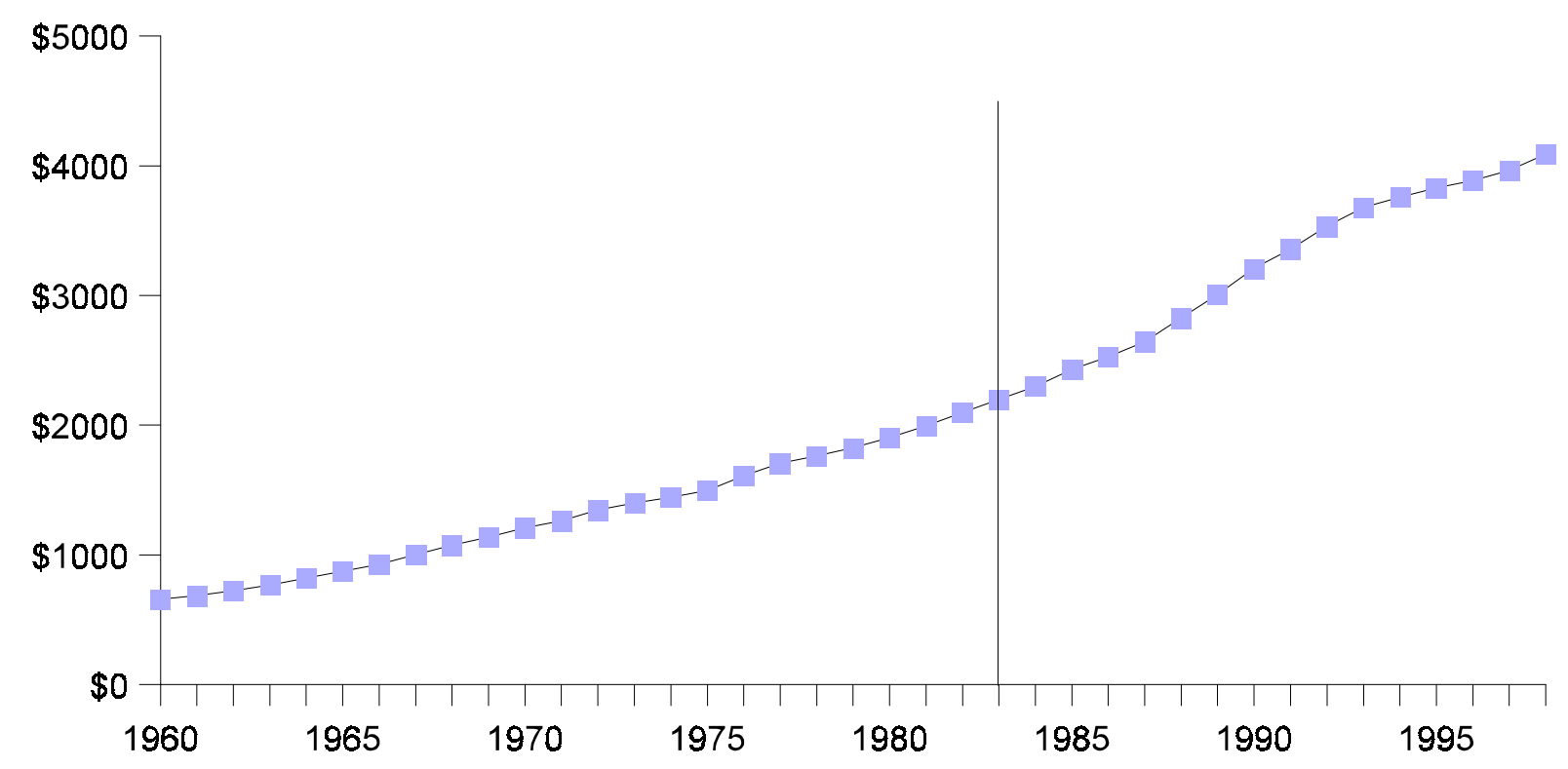

Note: Data are from the Center for Medicare and Medicaid Services. 
Figure 4: Youth Smoking Over Time

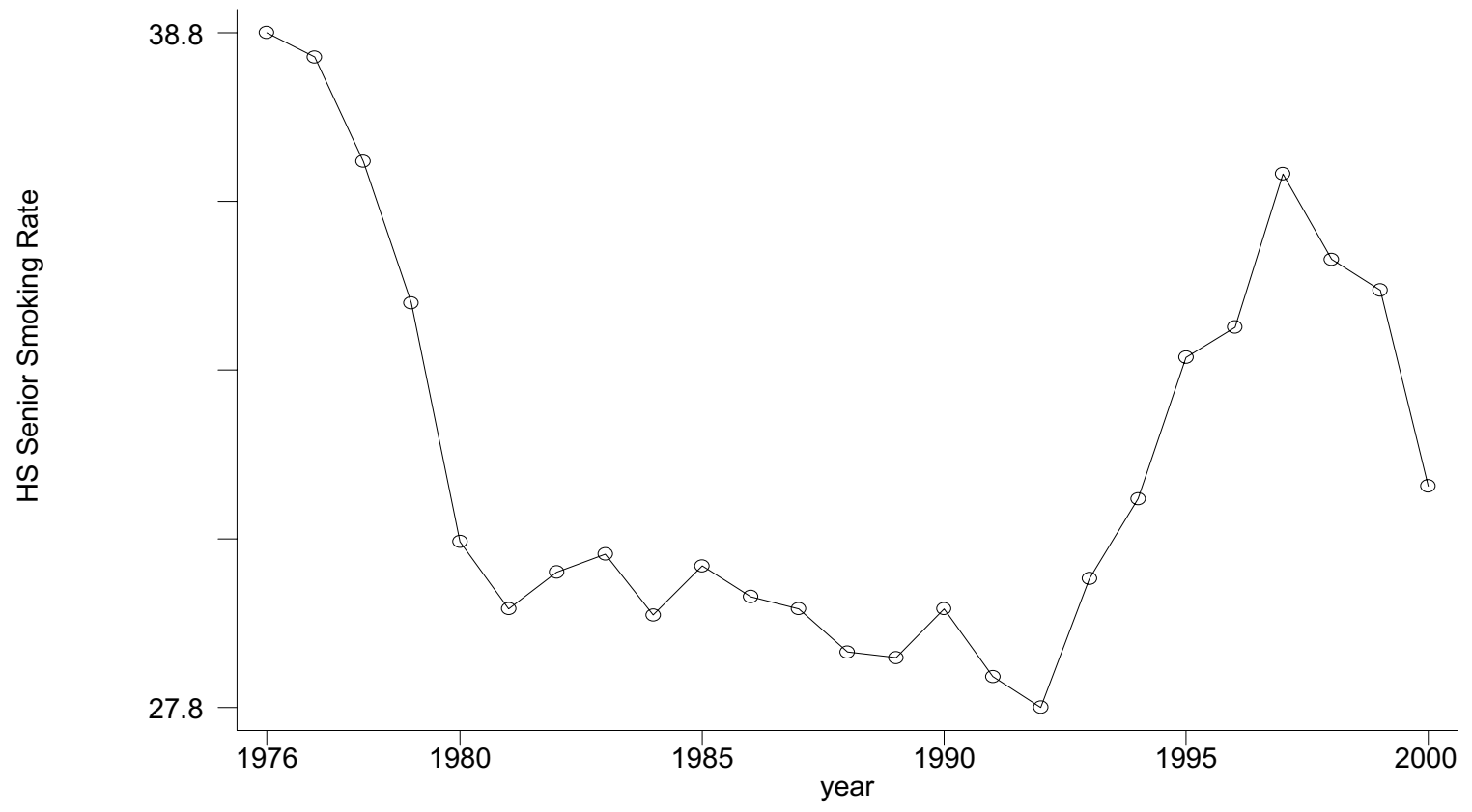

Note: Data are from the Monitoring the Future Survey. 


\section{Notes}

1. The classic reference on "job lock" is Madrian (1994). See Gruber (2001a) for a review of the literature on this topic.

2. Victor Fuchs' comments on this chapter, as well as his previous writings, discuss this question in more detail.

3. An earlier example of this difficulty could be found in the 1988 Medicare Catastrophic Care Act, which raised the Medicare premiums on higher income elderly to improve the benefits package for lower income elderly. This plan proved vastly unpopular with seniors and was repealed after two years.

4. For detailed discussions of the history of public insurance policy, see Gruber (1997, 2000).

5. This conclusion is not supported by some other studies in this area; see Gruber (2000) for a review.

6. This was a somewhat odd means of financing the adverse selection cost, since it would mean the highest lifetime premiums for those healthy enrollees who lived the longest.

7. Contributing to the desire for Federal regulation was the growing belief that insurance companies were using ERISA as a loophole. For example, a state might mandate that all insurers (except self-funded companies) provide a minimum level of mental health benefits. Insurers and companies that did not want to provide these benefits might convert the insurance product being sold into a self-funded plan. If the firm buying insurance were small, this seems to open it up to substantial risk of claims expense. But nothing prohibited the company from buying stop-loss coverage - often from the same insurer - to limit its maximum expense for any individual. This stop-loss insurance was not health insurance and thus was not subject to the mental health 
mandate. As a result, companies of all sizes could effectively skirt the regulatory mandates by becoming self-funded with little increase in risk.

8. For example, not all states imposed small group restrictions for firms with as few as 2 employees or as many as 50 employees.

9. Medical Savings Accounts (MSAs) are a catastrophic insurance product which provide low cost insurance with very high deductibles and/or copayments. Very few people took up these accounts, however, so we do not spend much time on them.

10. Based on data kindly provided to us by David Grabowski of the University of Alabama at Birmingham.

11. The economist Victor Fuchs (1994) noted that the tobacco tax used to fund part of the Health Security Act was the part of the plan most likely to improve health - this is a plan guaranteeing universal coverage with a generous set of benefits!

12. The discussion in this section draws heavily on Gruber (2001b).

13. Indeed, this settlement actually explicitly mandated that the payments be passed forward to prices!

14. The impact on industry profitability computed by Bulow \& Klemperer ignores the collusive aspects of price setting in this industry. As argued below, the settlement of state lawsuits by the industry may have actually increased profitability.

15. For example, the state settlement alone featured upfront payments to lawyers of $\$ 1.25$ billion, and ongoing payments of $\$ 500$ million per year. 